DOI: $10.19195 / 0080-3626.61 .3$

\author{
MICHAŁ BARTOSZAK
}

\title{
POZOSTAŁOŚCI KSIĘGOZBIORU PRYMASA STANISŁAWA KARNKOWSKIEGO W ARCHIWUM ARCHIDIECEZJALNYM W GNIEŹNIE
}

\begin{abstract}
Księgozbiór prymasa Stanisława Karnkowskiego jako przedmiot badań naukowych. Analiza fragmentu jego księgozbioru znajdującego się w Archiwum Archidiecezjalnym w Gnieźnie pod kątem tematyki, proweniencji i opraw. Nieznane lub niereprodukowane warianty wykorzystywanych superekslibrisów.
\end{abstract}

SŁOWA KLUCZOWE: Archiwum Archidiecezjalne w Gnieźnie, Stanisław Karnkowski, stare druki, badania proweniencyjne

Księgozbiór biskupa kujawsko-pomorskiego (1567-1581), a później arcybiskupa gnieźnieńskiego i prymasa Polski (1581-1603) Stanisława Karnkowskiego ${ }^{1}$ uznawany jest za jedną z większych bibliotek polskich XVI wieku. Nie doczekał się on jednak dotąd całościowego opracowania, na co wpływ ma także jego rozproszenie w różnych miejscach. Nie wyczerpują z pewnością tematu prace Stanisława Rybandta ${ }^{2}$, mające raczej charakter rozpoznawczy. Skłania to do zintensyfikowania poszukiwań rozproszonych woluminów w zasobach różnych instytucji bibliotecznych i archiwalnych, o których konieczności przekonują choćby badania

${ }^{1}$ Zob. J. Korytkowski, Arcybiskupi gnieźnieńscy, prymasowie i metropolici polscy od roku 1000 do roku 1821, czyli do połaczenia arcybiskupstwa gnieźnieńskiego z biskupstwem poznańskim. Wedtug źródeł archiwalnych, t. 3, Poznań 1889, s. 422-541; H. Kowalska, Karnkowski Stanisław, [w:] Polski Stownik Biograficzny (dalej: PSB), t. 12, Wrocław 1966-1967, s. 77-79.

2 S. Rybandt, Drukarskie oficyny niemieckie w orbicie zainteresowań polskiego dostojnika kościelnego prymasa Stanisława Karnkowskiego, [w:] E scientia et amicitia. Studia poświęcone profesorowi Edwardowi Potkowskiemu w sześćdziesięciolecie urodzin i czterdziestolecie pracy naukowej, pod red. M. Drzewieckiego, Warszawa-Pułtusk 1999, s. 159-165; idem, Ksiegozbiór prymasa Stanisława Karnkowskiego. Źródło badań nad kultura umysłowa dostojnika kościelnego XVI w., [w:] Z badań nad polskimi księgozbiorami historycznymi, t. 13, pod red. B. Bieńkowskiej, Warszawa 1992, s. 117-130; idem, Superekslibrisy prymasa Stanisława Karnkowskiego w Bibliotece Uniwersyteckiej w Warszawie, [w:] Z badań nad polskimi księgozbiorami historycznymi, t. 11, pod red. B. Bieńkowskiej, Warszawa 1991, s. 5-26. 
podjęte przez Kazimierza Rulkę we Włocławku ${ }^{3}$. Za zasadnością podjęcia takich działań przemawiać może również przykład Archiwum Archidiecezjalnego w Gnieźnie, w którego zasobach wspomniany Stanisław Rybandt zidentyfikował sześć ksiąg legitymujących się proweniencją Karnkowskiego ${ }^{4}$. Trwające w ramach projektu grantowego prace inwentaryzacyjne kierowane przez Piotra Pokorę ${ }^{5}$ pozwoliły na zidentyfikowanie w jego zasobach kolejnych 22 woluminów. Razem więc w Archiwum Archidiecezjalnym znajduje się 28 woluminów druków należących do prymasa Karnkowskiego - ponieważ część z nich to klocki introligatorskie, liczba druków wynosi 38 . W niniejszym artykule podjęto próbę ich scharakteryzowania zarówno na płaszczyźnie tematycznej odbijającej zainteresowania czytelnicze prymasa ${ }^{6}$, jak i na poziomie tegumentologicznym oraz proweniencyjnym. Dla ułatwienia orientacji w zasobie „karnkovianów” w Archiwum Archidiecezjalnym ich wykaz zamieszczono w Aneksie (katalogu) na końcu artykułu.

Przechowywany w Archiwum Archidiecezjalnym w Gnieźnie zespół druków należących niegdyś do prymasa w przeważającej mierze składa się z dzieł prawniczych, prace teologiczne są mniej liczne. Wzrost popularności literatury prawniczej w XVI wieku, dostrzegalny w wyposażeniu wielu prywatnych księgozbiorów tego okresu' ${ }^{7}$, znajduje zatem potwierdzenie w zachowanych w Gnieźnie egzemplarzach. W dziale książek z zakresu prawa znajdują się zarówno dzieła fundamentalne, jak i prace rzadsze.

Ciągle żywotne w XVI wieku i niezwykle popularne kodyfikacje cesarza Justyniana ${ }^{8}$, uznawane za podstawowe źródło do nauki prawa rzymskie-

${ }^{3}$ K. Rulka, Personalne ksiegozbiory historyczne w Bibliotece Seminarium Duchownego we Włocławku, „Archiwa, Biblioteki i Muzea Kościelne” 65, 1996, s. 362-364.

${ }^{4}$ S. Rybandt, Księgozbiór..., s. 122, wskazuje na woluminy o sygn.: Inc. 321, Inc. 655, PL 69, PL 75, PL 198, PL 320. Dwie ostatnie nie wykazują jednak żadnych cech pozwalających na włączenie ich do księgozbioru prymasa.

5 Projekt „Inwentaryzacja zasobu Biblioteki Katedralnej w Gnieźnie” prowadzony jest w ramach grantu finansowanego z Narodowego Programu Rozwoju Humanistyki MNiSW (nr 11H 12 0179 81).

6 B. Bieńkowska, Staropolski świat ksiązek, Wrocław 1976; K. Głombiowski, Problemy historii czytelnictwa, Wrocław 1966; K. Maleczyńska, Źródła do dziejów książki i bibliotek okresu renesansu, „Studia o Książce” 16, 1986, s. 25-26; B. Rok, Staropolskie książki jako źródto do badań nad mentalnościa, „Acta Universitatis Wratislaviensis. Historia” 170, 2004, s. 283-289.

7 L. Febvre, H.-J. Martin, Narodziny ksiażki, Warszawa 2014, s. 420-421.

8 Por. Catalogue of Books from the Library of Sigismund Augustus, King of Poland, in the Collection of the National Library of Russia in Saint Petersburg, pod red. M. Tkachenko, M. Bryndy, Warsaw 2015, nr 25-26; L. Grzebień, Biblioteka biskupa Hieronima Rozrażewskiego, „Archiwa, Biblioteki i Muzea Kościelne” 22, 1971, s. 102-103; J. Gwioździk, E. Różycki, Druki XVI wieku w zbiorach Biblioteki Katedralnej we Lwowie, Warszawa 2008, s. 51; B. Iwańska-Cieślik, Biblioteka kapituly katedralnej we Włocławku, Bydgoszcz 2013, s. 208-209, 221, 291, 294-295; A. Kawecka-Gryczowa, Biblioteka ostatniego Jagiellona. Pomnik Kultury Renesansowej, Wrocław 1988, nr 187-200; A. Lewicka-Kamińska, Renesansowy księgozbiór Mikołaja 
go ${ }^{9}$, a przeszczepione na grunt kościelny - w znacznej mierze również prawa kanonicznego ${ }^{10}$, reprezentowane są w zasobie Archiwum przez dwa woluminy. Pierwszy stanowi fragment dzieła Digestorum sev Pandectarum libri qvinqvaginta ex floretinis Pandectis repraesentati, wydanego w 1553 roku u florenckiego typografa Kosmy Medyceusza Lorenza Torrentina ${ }^{11}$ (katalog, poz. 17). Drugim jest Kodeks Justyniana w bazylejskim wydaniu Ivo Schöffera z 1536 roku: In Codicis Dn Iustiniani [...] Ex Repetita Praelectione Libros IX (katalog, poz. 30), opatrzony glosami Placentinusa (zm. 1192), profesora prawa rzymskiego na uniwersytetach Bolonii i Montpellier ${ }^{12}$.

Innym fragmentem Kodeksu cesarza Justyniana stało się grecko-łacińskie dzieło Nearōn Iustinianu Basileōs : tōn en tō nyn heuriskomenōn kai ōs euriskontai, biblion [...], wydrukowane w 1531 roku w Norymberdze przez Johanna Petreiusa (katalog, poz. 18) ${ }^{13}$. Wydanie Nowel obejmujących kolejne normy prawne, głównie związane z pozycją Kościoła w państwie, wieńczące działalność kodyfikacyjną Justyniana ${ }^{14}$, doczekało się prekursorskiego krytycznego opracowania dokonanego przez niemieckiego jurystę Gregora Haloandra ${ }^{15}$, którego działalność, wspierana przez norymberską radę miejską, uznana została za jedno z największych przedsięwzięć drukarskich oficyny Petreiusa ${ }^{16}$.

Oprócz tego komentarza, sporządzonego $\mathrm{w}$ duchu humanizmu prawniczego w wydaniu niemieckim ${ }^{17}$, w księgozbiorze prymasa znalazły się również dzieła innego współczesnego mu jurysty — Girolama Cagnola (1491-1551). Wysoko oceniane ${ }^{18}$ komentarze Pandektów i Kodeksu Justyniana zawarte zostały w wydanych w 1549 roku we Wenecji u Girolama Scota ${ }^{19}$ tomach Constitutiones et leges pri-

Czepla w Bibliotece Jagiellońskiej, Wrocław 1956, nr 86, 188; A. Obrębski, Volsciana: katalog renesansowego księgozbioru Piotra Dunina-Wolskiego, biskupa płockiego, Kraków-Warszawa 1999, nr 306-307; J. Tondel, Inkunabuły w zbiorach Biblioteki Wyższego Seminarium Duchownego w Pelplinie, Toruń-Pelplin 2007, nr 152.

9 D. Żołądź-Strzelczyk, Ideały edukacyjne doby staropolskiej: stanowe modele i potrzeby edukacyjne szesnastego i siedemnastego wieku, Warszawa-Poznań 1990, s. 145, 149.

10 A. Dębiński, Kościót i prawo rzymskie, Lublin 2008, s. 81-94.

11 Archiwum Archidiecezjalne w Gnieźnie (dalej: AAG), sygn. BKS 3294.

12 Piacentino, [hasło w:] Dizionario Biografico Degli Italiani, t. 83, 2015, http://www.treccani.it/enciclopedia/piacentino_(Dizionario-Biografico)/ [dostęp: 12.02.2017].

13 AAG, sygn. BK 905.

14 A. Dębiński, op. cit., s. 35; M. Kuryłowicz, Prawo rzymskie. Historia. Tradycja. Wspótczesność, Lublin 2003, s. 87.

15 Neue Deutsche Biographie, t. 7, Berlin 1966, s. 571.

16 J. Benzing, Die Buchdrucker des 16. und 17. im Deutschen Sprachgebiet, Wiesbaden 1963, s. 355; Neue Deutsche Biographie, t. 20, Berlin 2001, s. 262-263.

17 R. Wojciechowski, Z dziejów renesansowego humanizmu prawniczego, „Acta Universitatis Wratislaviensis. Prawo" 288, 2004, s. 91-102.

18 Gerolamo Cagnolo, [hasło w:] Dizionario Biografico Degli Italiani, t. 16, 1973, http:// www.treccani.it/enciclopedia/gerolamo-cagnolo_(Dizionario-Biografico)/ [dostęp: 12.02.2017].

19 E. Pastorello, Tipografi, Editori, Librai a Venezia Nel Secolo XVI, Firenze 1924, s. 140. 
mi, secundi, quinti, et duodecimi Pandectarum. [...] Tomus primus $[- \text { secundus }]^{20}$ (katalog, poz. 12).

Karnkowski zaopatrywał się nie tylko we współczesne mu objaśnienia prawa rzymskiego, ale także w dzieła starsze, wchodzące jednak w całości w skład włoskiej szkoły komentatorów średniowiecznych. Wśród nich znajdują się dwa druki Angela Gambiglioniego (ok. 1400-1461) wraz z komentarzem Francesca Accoltiego (1417/1418-1488): Super Institu(tiones) Opus [...] cu(m) casibus longis ${ }^{21}$ wydane w 1523 roku w lyońskiej oficynie Antoine’a du Ry nakładem Jacques'a Giunty ${ }^{22}$ (katalog, poz. 24-25). Obaj prawnicy uznawani za wiodących w swojej profesji należeli do jednych z najczęściej cytowanych jurystów swoich czasów ${ }^{23}$.

Księgozbiór Karnkowskiego wzbogaciły także wydania prac Bartolusa de Saxoferrata (1313/1314-1357). Dzieła „księcia prawników” (jak nazywa go Rafał Wojciechowski ${ }^{24}$ ) zebrane w czterech klockach w całości reprezentowane są przez druki oficyny lyońskiej Denisa Harsy'ego ${ }^{25}$. Najobficiej występujące komentarze poszczególnych części Corporis Iuris Civilis: Commentaria In Primam [-Secundam] Digesti veteris partem (wyd. 1550) ${ }^{26}$ (katalog, poz. 5); Commentaria In Primam [-Secundam] Infortiati partem (wyd. 1550) ${ }^{27}$ (katalog, poz. 6); Commentaria In Primam [-Secundam] Digesti Novi partem (wyd. 1550) ${ }^{28}$ (katalog, poz. 4); Commentaria Super Authenticis (wyd. 1549) ${ }^{29}$ (katalog, poz. 8) oraz Commentaria In Tres Libros Codicis (wyd. 1549) ${ }^{30}$ (katalog, poz. 7) opatrzone zostały uwagami Pietropaula Parisia (1473-1545), cieszącymi się niemałą popularnością wśród studentów prawa rzymskiego ${ }^{31}$. Zbiór uzupełniają Consilia, quaestiones, et tractatus (wyd. 1550) (katalog, poz. 9). Konsylia powstające na zamówienie

${ }^{20}$ AAG, sygn. BK 1566.

21 AAG, sygn. BK 725, BK 1048.

22 Encyklopedia wiedzy o ksiażce, pod red. A. Birkenmajera, Wrocław 1971, kol. 796-797; J. Gwioździk, E. Różycki, op. cit., s. 69.

23 Angelo Gambiglioni, [hasło w:] Dizionario Biografico Degli Italiani, t. 52, 1999, http:// www.treccani.it/enciclopedia/angelo-gambiglioni_(Dizionario-Biografico)/ [dostęp: 12.02.2017]; Francesco Accolti, [hasło w:] Dizionario Biografico Degli Italiani, t. 1, 1960, http://www.treccani. it/enciclopedia/francesco-accolti_(Dizionario-Biografico)/ [dostęp: 12.02.2017].

24 R. Wojciechowski, Bartolus de Saxoferrato (1313/1314-1357), [w:] Wybrane problemy nauki i nauczania prawa, pod red. E. Kozerskiej, P. Sadowskiego, A. Szymańskiego, Opole 2010, s. 128.

25 Działać miał w latach 1523-1554. Po nim oficynę przejął syn Antoine - zob. J. Gwioździk, E. Różycki, op. cit., s. 69.

26 AAG, sygn. BK 944.

27 AAG, sygn. BK 964.

28 AAG, sygn. BK 966.

29 AAG, sygn. BK 965.

30 Ibidem.

31 Pietropaolo Parisio, [hasło w:] Dizionario Biografico Degli Italiani, t. 81, 2014, http:// www.treccani.it/enciclopedia/pietropaolo-parisio_(Dizionario-Biografico)/ [dostęp: 12.02.2017]. 
rozmaitych podmiotów stanowiły rodzaj porad prawnych uwarunkowanych konkretnymi sytuacjami. Tworzone były głównie przez przedstawicieli późnośredniowiecznej jurysprudencji. Ich późniejsze drukowane wydania dowodnie świadczą jednak (poprzez ich praktyczny wymiar) o ciągłej żywotności i aktualności ${ }^{32}$. Użytecznym dodatkiem do prac Bartolusa był Index Sive Repertorium Singulare in lecturas Bartoli a Saxo [...] (wyd. 1550) ${ }^{33}$ (katalog, poz. 10) umożliwiający zorientowanie się w licznych pracach włoskiego prawnika.

Zainteresowanie Karnkowskiego konsyliami zamanifestowało się również w następnym woluminie, zawierającym porady Lodovica Pontana (ok. 1409-1439) (wyd. 1545) (katalog, poz. 31) i Franceschina Cortiego (ok. 1470-1533) (wyd. 1547) (katalog, poz. 20) oraz Consilia [...] Vna cum [...] repertorio (wyd. 1543) ${ }^{34}$ (katalog, poz. 19).

Włoski nurt prawniczy reprezentują także prace dotyczące prawodawstwa Królestwa Neapolu, do których wliczają się Commentaria super ritibus magnae Curiae Vicariae regni Neapolis [...] Accesserunt etiam commentarii [...] Anibalis Troysii Cavensis alias impressi, ac [...] Ioannis Francisci Scaglioni super eisdem ritibus autorstwa Prospera Caravity (zm. 1580) ${ }^{35}$ wydane w 1563 roku w weneckiej oficynie Marca de Marii ${ }^{36}$ (katalog, poz. 13).

Inną, powiązaną jednak geograficznie, tematykę prawną podjął Matteo d'Afflitto (ok. 1448-1528) w pracy In utriusque Siciliae, Neapoliq(ue) sanctiones, et constitutiones wydrukowanej w Wenecji u bliżej nieznanego typografa w 1562 roku $^{37}$ (katalog, poz. 1). Pochodzący z Neapolu d'Afflitto, profesor prawa, przewodniczył również Camera della Sommaria (organ sądowy odpowiedzialny za sprawy podatkowe) ${ }^{38}$. Znany był głównie ze swych Decisiones Neapolitanae, obecnych w księgozbiorach Mikołaja Czepiela ${ }^{39}$, jak też kanonika lwowskiego Wojciecha Perlickiego ${ }^{40}$.

Ciekawie na tle poprzednich prac jawi się dzieło Ad Obertum Ortensium, de Beneficiis, Commentarii, Methodo in eundem subiecti wydane w lyońskiej drukarni Sébastiena Gryphe’a w roku $1549^{41}$ (katalog, poz. 3), skupiające się całościowo

32 R. Wojciechowski, Średniowieczne „Consilia” prawnicze, „Acta Universitatis Wratislaviensis. Przegląd Prawa i Administracji” 59, 2004, s. 169-176.

33 AAG, sygn. BK 965.

34 AAG, sygn. BK 1364.

35 AAG, sygn. BK 897.

36 Okresy jego działalności typograficznej obejmują lata: 1558, 1560-1563, 1565-1566, 1569

— zob. F. Ascarelli, La Tipografia Cinquecentina Italiana, Firenze 1953, nr 153.

37 AAG, sygn. BK 6088.

38 Matteo D'Afflitto, [hasło w:] Dizionario Biografico Degli Italiani, t. 31, 1985, http://www. treccani.it/enciclopedia/matteo-d-afflitto_(Dizionario-Biografico)/ [dostęp: 14.02.2017].

39 A. Lewicka-Kamińska, op. cit., nr 51.

40 J. Gwioździk, E. Różycki, op. cit., nr kat. 4.

41 AAG, sygn. BK 762. 
na problematyce prawa lennego. Obecność pracy Éguinera Barona (ok. 14951550), profesora obojga praw w Angers, a od 1542 roku w Bourges, propagującego nauczanie prawa more gallico ${ }^{42}$, radykalnie sprzeciwiającego się wykorzystywanym na Półwyspie Apenińskim wzorcom ${ }^{43}$, wskazywać może na chęć śledzenia przez Karnkowskiego aktualnych prawoznawczych prądów umysłowych ${ }^{44}$.

Niezwykle popularną, wydaną ośmiokrotnie w XVI wieku pracą były Illustrium Controversiarum Aliarumque Usu Frequentium Libri tres autorstwa Fernanda Vazqueza Menchacy (1512-1569). Nabyta przez arcybiskupa edycja wydana została w 1595 roku w Wenecji przez Girolama Scota ${ }^{45}$ (katalog, poz. 35). Zagadnienia poruszane w 6-tomowym dziele hiszpańskiego jurysty, profesora obojga praw w Salamance i Sewilli, a także członka rady i kamery Kastylii, w całości skupiające się na problemach prawa międzynarodowego, w 2-tomowej części posiadanej przez prymasa ogniskują się wokół kwestii władzy Hiszpanów w Nowym Świecie oraz swobodnego poruszania się po morzach ${ }^{46}$.

Literaturę z zakresu prawa rzymskiego uzupełniają także prace Ulricha Zasiusa (1461-1536), profesora prawa we Fryburgu Bryzgowijskim ${ }^{47}$ - In Usus Feudorum Epitome (Bazylea, Joahnn Bebel 1535) (katalog, poz. 37) oraz Stefana Federiciego (XVI wiek) z Brescii ${ }^{48}$ - De Interpretatione Iuris Commentarii IIII (Frankfurt n. Menem, Christian Egenolff 1535) ${ }^{49}$ (katalog, poz. 23).

Ilościowo skromniej przedstawiają się dzieła z zakresu prawa kanonicznego obejmujące zaledwie sześć woluminów. W ich skład weszła fundamentalna praca Marcina Polaka (ok. 1225/1230-1279) Margarita Decreti Seu Tabula Martiniana wydana w 1491/1493 roku w norymberskiej oficynie Antona Kobergera ${ }^{50}$ (katalog, poz. 29), która poprzez pokaźną liczbę alfabetycznie ułożonych ok. 800 haseł pojawiających się w Dekrecie Gracjana stanowiła niezwykle pożądaną pomoc dla prawników na przestrzeni kilku stuleci, o czym przekonują zachowane rękopisy

${ }^{42}$ M. Erbe, François Baudin (1520-1573). Biographie eines Humanisten, Heidelberg 1978, s. $65-66$.

43 A. Dziadzio, Powszechna historia prawa, Warszawa 2011, s. 116; R. Wojciechowski, Z dziejów..., s. 95-100.

44 Wskazać warto również na obecność komentarza Éguinera Barona do kodyfikacji Justyniana w księgozbiorze biskupa kujawskiego Hieronima Rozrażewskiego (L. Grzebień, op. cit., s. 102).

45 AAG, sygn. BK 845.

46 C. Barcia Trelles, Fernando Vázquez de Menchaca 1512-1569, comunidad internacional, imperio y libertad de los mares, „Anales de la Universidad de Murcia” 2, 1932, nr 2, s. 3-14.

47 Allgemeine Deutsche Biographie, t. 44, 1898, s. 708-715.

48 G. Vismara, Ius Mediolani: studia di storia del diritto milanese offerti dagli allievi a Giulio Vismara, Milano 1996, s. 75.

49 AAG, sygn. BK 11074.

50 AAG, sygn. Inc. 655. 
w liczbie przeszło 120 oraz aż 22 wydania drukowane z lat $1480-1500^{51}$, jak też przetrwałe w licznych polskich księgozbiorach egzemplarze ${ }^{52}$.

Za nie mniej sztandarową pracę z prawa kanonicznego uchodziła Decretalium copiosum argumentum [...], wydrukowana w 1510 roku przez paryskiego typografa Bertholda Remboldta ${ }^{53}$ (katalog, poz. 16). Popularne Dekretaty Grzegorza IX (zm. 1241) powstały w celu zaradzenia nieporządkowi prawnemu, który panował na początku XIII wieku. Redakcja norm zlecona Rajmundowi z Pennfort zaowocowała w 1234 roku zbiorem autentycznym, powszechnym, jednym i wyłącznym ${ }^{54}$, świadcząc dobitnie o centralistycznych dążeniach papiestwa ${ }^{55}$. Dekretalistami tego wydania byli profesorowie prawa kanonicznego Ioannes Andreae (ok. 1270-1348) $)^{56}$ oraz Lodovico Bolognini (1446-1508) $)^{57}$.

Do współczesnego nurtu prawoznawczego należało już dzieło Commentaria Et Tractatus Hucusque Editi, atque nunc recens in unum collecti, et in tres tomos distincti Martina Azpilcuety (1493-1586) wydrukowane przez Damiana Zenara w Wenecji w roku $1588^{58}$ (katalog, poz. 2).

W skład prymasowskiego księgozbioru weszło również dzieło Filippa Decia (1454-1536) Decretalibus Luculentus, atque Memoria Nostra colendus, Prudentissimi, Utraque censura [...] komentujące papieskie dekretały. Wydane zostało w 1544 roku w lyońskiej oficynie Jacques'a Beriona nakładem Jacques’a Giunty ${ }^{59}$ (katalog, poz. 21).

Mniej natomiast znanym przedstawicielem francuskiego środowiska prawnego był André Tiraqueau (1488-1558), którego wydrukowana w 1554 roku u Guillaume'a Rouillé w Lyonie praca De Utroque Retractu, Municipali, et Conventionali, Commentarii Duo [...] $]^{60}$ (katalog, poz. 34) koncentruje się wokół zagadnień prawa małżeńskiego. Zainteresowanie osobą i dziełem św. Karola Boromeusza (1538-1584) przejawia się w dwóch kolejnych woluminach należących

51 K. Grodziska-Ożóg, Marcin Polak i jego twórczość, „Nasza Przeszłość” 58, 1982, s. 192; J. Soszyński, Kronika Marcina Polaka i jej średniowieczna tradycja rękopiśmienna w Polsce, Warszawa 1995, s. 56; T. Ulewicz, Wśród impresorów krakowskich doby renesansu, Kraków 1977, s. 48.

52 Między innymi: B. Iwańska-Cieślik, Biblioteka..., s. 291; A. Obrębski, op. cit., nr 519; W. Szelińska, Biblioteki profesorów Uniwersytetu Krakowskiego w XV i w początkach XVI wieku, Wrocław 1966, s. 165; J. Tondel, op. cit., nr 319-323.

53 AAG, sygn. BK 6476.

54 I. Subera, Historia źródet i nauki prawa kanonicznego, Warszawa 1977, s. 97-102.

55 R. Sobański, Europa obojga praw, Katowice 2006, s. 52.

56 A. Lewicka-Kamińska, op. cit., s. 73.

57 Ludovico Bolognini, [hasło w:] Dizionario Biografico Degli Italiani, t. 11, 1969, http:// www.treccani.it/enciclopedia/ludovico-bolognini_(Dizionario-Biografico)/ [dostęp: 15.02.2017].

58 AAG, sygn. BK 1478.

59 AAG, sygn. BK 6043.

60 AAG, sygn. BKS 1196. 
do prymasa. Pierwszy z nich zawierający Constitutiones et decreta condita in provinciali synodo Mediolanensi Quinta wydany został w 1580 roku w Mediolanie u Michelego Tiniego ${ }^{61}$ (katalog, poz. 15). Organizacja archidiecezji mediolańskiej prowadzonej przez Karola Boromeusza uchodziła w tym okresie za wzorcową dla wszystkich podobnych działań implementacji dokonań Soboru Trydenckiego $\mathrm{w}$ diecezjach ${ }^{62}$. Ustawy piątego synodu prowincji mediolańskiej mogły stanowić zatem ciekawe źródło porównań i inspiracji dla podobnych przedsięwzięć Karnkowskiego w Polsce.

Dowody ściślejszych relacji łączących Boromeusza i Karnkowskiego odnaleźć można w kolejnym dziele zredagowanym przez Giovanniego Botera (1544-1616) Epistolarum Ilustrissimi ac Reuerendissimi D. D. Caroli Cardinalis Borromaei nomine scriptarum. Libri II $\mathrm{w}$ wydaniu paryskiej oficyny Thomasa Periera $\mathrm{z}$ roku $1586^{63}$ (katalog, poz. 11), zawierającym korespondencję kardynała i arcybiskupa Mediolanu, w tym liczne listy wymieniane z samym właścicielem woluminu ${ }^{64}$.

Łącznie z tym dziełem $\mathrm{w}$ księgozbiorze prymasa znalazły się prace uchodzące za klasyki myśli teologicznej. Szczytowym osiągnięciem encyklopedycznych zapędów średniowiecza było dzieło dominikanina Wincentego z Beauvais (ok. 1194-1264) Speculum maius, tutaj obecne jedynie we fragmencie Speculum morale wydanym u Jeana Mentelina w Strasburgu w 1476 roku $^{65}$ (katalog, poz. 36), dokończonym najpewniej już po śmierci kompendysty ${ }^{66}$. Całość dzieła, powszechna w księgozbiorach polskich schyłku średniowiecza, wydawana jeszcze była drukiem po połowę XVIII wieku ${ }^{67}$. Łącznie z encyklopedią Wincentego z Beauvais w zbiorze prymasa obecne były Quaestiones Disputatae [...] św. Tomasza z Akwinu wydrukowane w Paryżu u François Honorata w 1557 roku $^{68}$ (katalog, poz. 33).

Innym komponentem biblioteki stało się Exegesis Absolutissima Iuxta ac brevissima Evangelicae veritatis, erorrumque et mendaciorum quae sunt cum in

61 AAG, sygn. BK 249.

62 W.H. Carroll, Historia chrześcijaństwa. T. 4, Podział chrześcijaństwa, Wrocław 2011, s. 326-327; W. Góralski, Reforma trydencka w diecezji i prowincji mediolańskiej w świetle pierwszych synodów kard. Karola Boromeusza, Lublin 1988, s. 13-16.

63 AAG, sygn. BK 6346.

${ }^{64}$ S. Bielański, Giovanni Botero: historyk i pisarz polityczny epoki kontrreformacji, Kraków 1995, s. 105.

65 AAG, sygn. Inc. 321.

66 A. Fijałkowski, ,,Puer eruditus”. Idee edukacyjne Wincentego z Beauvais (ok. 1194-1264), Warszawa 2001, s. 28-29.

67 Ibidem, s. 67-84. Probierzem popularności dzieła Wincentego z Beauvais w XV-wiecznej Polsce może być jego wykorzystywanie w nauce na wydziale artium Uniwersytetu Krakowskiego w I połowie tego wieku. W bibliotekach polskich zachowało się do dziś 108 inkunabułów, głównie w wersji całościowej, w XVII wieku wydawane było jako speculum magnum lub exemplarum.

68 AAG, sygn. BKS 745. Na temat dzieła zob. A. Kenny, Tomasz z Akwinu, Warszawa 1999, s. 17 nn.; J.A. Weisheipl, Tomasz z Akwinu: życie, myśl i dzieło, Poznań 1985, s. 165-170. 
Confessione Lutherana Cesa(rea) Maiestati in comitis Augusten(sibus) exhibita [...] Johannesa von Deventera (zm. 1554) wydane w 1535 roku w kolońskiej drukarni Melchiora von Neussa ${ }^{69}$ (katalog, poz. 26). Słynący z kazań katolicki duchowny dziełem tym jako pierwszy zaatakował przyjęte w 1530 roku wyznanie luterańskie ${ }^{70}$.

W jednym woluminie z drukiem nadreńskiego kaznodziei znalazł się Catechismus, to jest nauka barzo pożyteczna każdemu krześcijaninowi wydrukowany przez krakowską oficynę Heleny Unglerowej ok. 1543 roku (katalog, poz. 32). Pomimo przeprowadzonej w XX wieku restauracji klocka, połączonej z zatratą dawnej oprawy oraz brakiem znaku własnościowego Karnkowskiego w tej części woluminu, jednolity format arkuszy, a także identyczny kolor barwionych obcięć bloku wskazują na pierwotne współoprawienie dzieł i zarazem posiadanie klocka przez prymasa.

Przypisywany głównie Mikołajowi Rejowi (1505-1569), spisany po raz pierwszy w języku polskim katechizm przerywał deficyt tego typu literatury dostępnej w języku pospolitym ${ }^{71}$. O jego popularności świadczyć może dodruk dzieła ok. 1549 roku przez prężnie działającą w latach 40. XVI wieku oficynę Heleny Unglerowej $^{72}$. Stonowana forma Rejowej parafrazy luterańskiego katechizmu Urbana Rhegiusa, „brak jednoznaczności pod względem wyznaniowym”73 czyniły z niego produkt skierowany do szerokiego kręgu odbiorców XVI-wiecznego społeczeństwa polskiego.

W kolejnym klocku ${ }^{74}$ zbierającym dzieła teologiczne współczesnych Karnkowskiemu autorów odnaleźć można pracę Camilla Cauzia Scholia Pro Religione wydaną u Francesca Lorenziniego w Wenecji w roku 1559 (katalog, poz. 14). Wydana także w Wenecji, tym razem u Francesca Rampazetta, w 1556 roku praca Boni Pastoris Exemplum Ac Specimen Singulare autorstwa Pietra Francesca Ziniego (1520-1573) (katalog, poz. 38), kanonika w Weronie oraz profesora teologii

69 AAG, sygn. PL 108b.

70 Neue Deutsche Biographie, t. 10, Berlin 1974, s. 547; R. Stupperich, Schriften von katolischer Seite gegen die Täufer, Münster 1980, s. 42.

71 D. Kuźmina, Katechizmy w Rzeczypospolitej XVI i początku XVII wieku, Warszawa 2002, s. 81-87; T. Witczak, Studia nad twórczościa Mikołaja Reja, Warszawa-Poznań 1975, s. 91-120. Dostępna w tym okresie była jedynie pozbawiona tłumaczenia łacińska wersja katechizmu Georga Witzela. Wydany z kolei u Hieronima Wietora w 1543 roku druk Pańskiej modlitwy krześcijańskiey, nauczone y mądre wyłożenie - zgodnie z opinią W. Pawlika - jedynie ,nawiązywał do podstawowych zagadnień katechizmowych" (idem, Katechizmy w Rzeczypospolitej od XVI do XVIII wieku. Katechizm i produkcja, Lublin 2010, s. 88-90).

72 A. Kawecka-Gryczowa, Helena Unglerowa, [w:] Drukarze dawnej Polski: od XV do XVIII wieku. T. 1, Małopolska. Cz. 1, Wiek XV-XVI, pod red. eadem, Wrocław 1983, s. 319.

73 D. Kuźmina, op. cit., s. 133.

74 AAG, sygn. BKS 5251. 
i filozofii moralnej na uniwersytecie w Padwie ${ }^{75}$, stanowiła natomiast wskazówki duszpasterskie.

Kończące klocek dzieło Depulsio calumniarum, quibus Athanasius quidam in epistola, et alii nonnuli, cardinalem insectantur opuściło drukarnię Sebalda Mayera w Dilingen w 1559 roku (katalog, poz. 22). Za osobę kryjącą się pod imieniem Atanazego uznaje się Pietra Paula Vergeria (1498-1565). Krótkim tekstem będącym w posiadaniu prymasa niezidentyfikowany autor odpierał zarzuty wysuwane przez ekskomunikowanego biskupa ${ }^{76}$.

Przechowywana do dzisiaj w gnieźnieńskim Archiwum jest również książka zawierająca pracę Marcina Kromera (1512-1589) Monachus sive colloquiorum de religione libri $I V$ wydaną we wspomnianej oficynie Maternusa Cholinusa w 1568 roku $^{77}$ (katalog, poz. 28). Dzieło, stanowiące łacińską wersję powstałej pierwotnie po polsku pracy Rozmowy dworzanina z mnichem z lat 1551-1554, cieszyło się w Polsce sporą popularnością, za granicą ustępując zdecydowanie miejsca podobnemu tematycznie dziełu Stanisława Hozjusza. Utwór ułożony w formie dialogu między reprezentantami obozu protestanckiego (dworzanin) i katolickiego (mnich) zbijał hasła szerzącego się nowinkarstwa religijnego ${ }^{78}$.

Woluminem będącym w posiadaniu Stanisława Karnkowskiego najprawdopodobniej jedynie chwilowo (o czym szerzej dalej) jest książka kryjąca pracę Adriana Junga (pod nazwiskiem Karnkowskiego) ${ }^{79}$ Messiasz Albo Kazania o Upadku Y Naprawie Rodzaiu Ludzkiego [...] w wydaniu z dołączonym dziełem Kazanie o dwojakim kościele chrześcijańskim, wydrukowanym u wdowy i dziedziców Jana Wolraba I w roku $1597^{80}$ (katalog, poz. 27).

W przechowywanej w Archiwum Archidiecezjalnym w Gnieźnie części księgozbioru Stanisława Karnkowskiego najliczniejszą zatem grupę stanowią druki prawnicze. Wynikało to z charakteru wykształcenia prymasa, jak też i podejmowanej przezeń działalności zawodowej, a przede wszystkim kościelnej, najwyraźniej dostrzegalnej w posiadaniu kodyfikacji konstytucji synodalnych. Dobór

75 G. Moroni, Dizionario di erudiozione storico-ecclesiastica, t. 93, Venezia 1859, s. 224.

76 Allgemeine Deutsche Biographie, t. 39, 1895, s. 617-621; T. Moskal, Książka w kulturze sandomierskiego środowiska kolegiackiego do 1818 roku, Lublin 2013, s. 43.

77 AAG, sygn. PL 69.

78 A. Bruździński, Historyczne tło konfliktu polskiego duchowieństwa i świeckich w wieku XVI: na podstawie „Rozmów dworzanina z mnichem” Marcina Kromera, „,Roczniki Historii Kościoła” 1, 2009, s. 101-121; J. Jezierski, Przedmiot sporu z luteranami w „Rozmowie dworzanina z mnichem" Marcina Kromera, [w:] Marcin Kromer i jego czasy (1512-1589). W 500-lecie urodzin biskupa warmińskiego Marcina Kromera, pod red. S. Achremczyka, Olsztyn 2012, s. 37-54; H. Barycz, Kromer Marcin, [w:] PSB, t. 15, Wrocław 1970, s. 321-322; M. Rechowicz, Teologia pozytywno-kontrowersyjna: szkoła polska w XVI wieku, [w:] Dzieje teologii katolickiej w Polsce. T. 2, Od Odrodzenia do Oświecenia. Cz. 1, Teologia humanistyczna, pod red. idem, Lublin 1975, s. $67-68$.

79 B. Natoński, Jung Adrian, [w:] PSB, t. 11, Wrocław 1964, s. 326.

80 AAG, sygn. PL 322. 
tych dzieł dobitnie świadczy o umyśle podążającym raczej za tradycyjną nauką prawną, stawiającą bardziej na użyteczność i praktyczne potrzeby.

Drobniejszy zespół prac związanych z teologią z trudem umożliwia wyciąganie jakichś ogólniejszych wniosków. Symptomatyczna wydaje się jednak obecność prac uchodzących za klasyczne, jak również aktualnych tekstów zagranicznych i krajowych, pozytywnie świadcząca o szerokich zainteresowaniach właściciela woluminów.

Narastający stopniowo księgozbiór wykazuje różne źródła i okres nabywania poszczególnych książek. Z rozważań wyłączony został (podobnie jak wcześniej) wolumin o sygnaturze PL $75 \mathrm{~b}$ adl. — z racji zagubienia i niemożności weryfikacji podanych przez Leona Formanowicza zawartych wewnątrz wpisów ${ }^{81}$. Spośród ustalonych 28 woluminów w 25 przypadkach ich pierwszym właścicielem był sam Stanisław Karnkowski. W pozostałych — dwukrotnie prymas uzyskał je od archidiakona gnieźnieńskiego i kanonika kujawskiego Stanisława Dąbrowskiego (zm. 1575), raz natomiast przejął wolumin od Walentego Kuczborskiego (1525-1572), kanonika krakowskiego.

Wskazywana już w literaturze jednokierunkowa migracja książek na linii Dąbrowski-Karnkowski ${ }^{82}$ reprezentowana jest w Gnieźnie dwoma kolejnymi przykładami. Pierwszy z nich ${ }^{83}$ stanowi część liczniejszej serii komentarzy Gregora Haloandra do Corpus Iuris Civilis (Norymberga, Johannes Petreius 1529-1531), której pozostałe tomy, również z proweniencjami Dąbrowskiego i Karnkowskiego, przechowywane są obecnie w Archiwum Diecezjalnym w Lowiczu ${ }^{84}$. Identyczna z tamtymi oprawa woluminu znajdującego się w Gnieźnie (zachowała się jedynie górna okładzina) wykonana jest z tektury obciągniętej czarną skórą pokrytej złoconymi tłoczeniami tworzącymi podwójne strychulcowe ramki połączone w narożnikach. W kątach prostokątnego zwierciadła widoczne są jeszcze drobne floralne wyciski. Na środku umieszczony jest natomiast superekslibris introligatorski z herbem Poraj i literami S(TANISLAUS) / D(AMBROWSKI), powyżej którego znajduje się zatarta częściowo data oprawienia bloku, zapewne w 1532 roku $^{85}$. Wykorzystany papier pochodzący z Mogiły ${ }^{86}$ wskazuje prawdopo-

81 L. Formanowcz, Katalog druków polskich XVI-go wieku Bibljoteki Kapitulnej w Gnieźnie, Poznań 1930, nr 202, wskazał na wpis świadczący o posiadaniu woluminu przez kanonika Stanisława Grota.

82 K. Rulka, op. cit., s. 362; Z. Skiełczyński, Superekslibrisy z Biblioteki Kapitulnej w Łowiczu, Łowicz 1993, s. 3-4. J. Korytkowski pisze ponadto o przyjaźni łączącej obu duchownych — zob. idem, Prataci i kanonicy, Gniezno 1883, s. 202 (cz. 2).

83 AAG, sygn. BK 905.

84 Z. Skiełczyński, op. cit., s. 3-4.

85 AAG, sygn. BK 905, widoczne jest: $X X X$ [?] II. Najpewniej oprawa wykonana została, jak pozostałe zachowane w Archiwum Diecezjalnym w Łowiczu, w 1532 roku (Z. Skiełczyński, op. cit., s. 4).

86 W. Budka, Znaki wodne papierni w Rzeczypospolitej Polskiej XVIw., [w:] Papiernie w Polsce XVI wieku, wyd. i uzup. W. Budka, Wrocław 1971, nr 46, 49; J. Siniarska-Czaplicka, Katalog 
dobnie na wyrób krakowskiego introligatora. Oprócz superekslibrisu archidiakon gnieźnieński posiadanie woluminu potwierdził jeszcze dodatkowo odręcznym wpisem Stan(islaus): Dambrowsky znajdującym się obok pieczęci Karnkowskiego. Drugim woluminem przejętym od Dąbrowskiego jest książka o sygn. BK 725, oprawiona na nowo po śmierci prymasa za sprawą Wincentego de Sevé (o czym szerzej dalej).

Dowodem bliższej znajomości Stanisława Karnkowskiego z Walentym Kuczborskim wydaje się być klocek introligatorski zbierający prace wydane w latach 1556-1559 przez Camilla Cauzia, Pietra Francesca Ziniego i Pietra Paula Vergeria ${ }^{87}$. Niepozorny gabarytowo wolumin z oprawą wykonaną z pergaminu na tekturze kryje odręczne wpisy Kuczborskiego ${ }^{88}$ i Jakuba Lempickiego $(1553-1608)^{89}$, kanonika gnieźnieńskiego i opata lubińskiego, a także pieczęć Karnkowskiego. Przypuszczać można, że pracujący wraz z przyszłym prymasem w latach 60 . XVI wieku w kancelarii królewskiej Kuczborski (wypełniał tam zadania sekretarza królewskiego) ${ }^{90}$ mógł podarować Karnkowskiemu (bądź wymienić się z nim) ową książkę, którą ten przekazał z kolei swojemu zaufanemu współpracownikowi Łempickiemu ${ }^{91}$. Do Gniezna klocek powędrował najpewniej po kasacie klasztoru benedyktynów lubińskich w XIX wieku².

W zależności od okresu życia prymasa sposób oznaczania jego ksiąg ulegał zmianie. $Z$ najwcześniejszym etapem gromadzenia księgozbioru związać należy odręczne wpisy, które figurują w czterech woluminach. Nabycie trzech z nich nastąpiło przypuszczalnie w czasie studiów zagranicznych Karnkowskiego (1545przed 1550) na użytek bieżącej nauki. Posiadanie prac Fillipa Decia (Lyon 1544), Lodovica Pontana w jednym woluminie z dziełami Franceschina Cortiego (Lyon 1543-1547) oraz Girolama Cagnola (Wenecja 1549) zaznaczyło się w jednolicie brzmiącym wpisie: Stanislai Karnkowski ${ }^{93}$, umieszczanym każdorazowo w dolnych partiach strony tytułowej druku. Odrębnym przypadkiem jest nota znajdująca się w traktacie prawniczym André Tiraqueau (Lyon 1554): Sum Stanislai Carncowski Referendarii Cvriae Sacre R(egiae) M(aiesta)tis ${ }^{94}$, jak wynika z jej treści — naniesiona przez Karnkowskiego w czasie sprawowania urzędu referendarza

filigranów czerpalni Rzeczypospolitej zebrany z papieru druków tloczonych w latach 1500-1800, Łódź 1983, nr 688-693.

87 AAG, sygn. BKS 5251.

88 Ibidem, Valentinus Cusborski [...].

89 Ibidem, Iacobus Lempicki Ab(bas) Mon(asterii) Lub(inensis).

90 J. Tazbir, Kuczborski Walenty, [w:] PSB, t. 16, Wrocław 1971, s. 73.

91 J. Korytkowski, Prałaci, t. 2, Gniezno 1883, s. 523.

92 J. Ostrowski, Bibljoteka klasztoru benedyktynów w Lubiniu, z 3-ma rycinami (autografy), Poznań 1929, s. 10. Na taką wędrówkę woluminu wskazuje los księgozbioru Kuczborskiego, który w całości po śmierci kanonika przekazany został do Kolegium Większego Uniwersytetu Krakowskiego (J. Tazbir, op. cit., s. 73).

93 AAG, sygn.: BK 1364, BK 1566, BK 6043.

94 AAG, sygn. BKS 1196. 
koronnego (1558-1563). Oprawa kryjąca druk wykonana jest z tektury obciągniętej białą świńską skórą pokrytą profuzją rozmaitych ślepych tłoczeń radełkowych, tworzących cztery ramki oddzielone strychulcami. W najbardziej zewnętrznej widoczne są popiersia reformatorów z zaślepionymi podpisami uniemożliwiającymi ich odczytanie ${ }^{95}$, między którymi umieszczono ornamenty roślinne. Kolejną ramkę wypełniają figuralne sceny ukazujące odpowiednie fragmenty biblijne z podpisami (1. SV(PER) SOLIVM DAVI(D) (Jr 17,25); 2. DE PLENITVDINE (J 1,16); 3. DATA EST MIHI O(MNIA POTESTAS) (Mt 28,18); 4. DE PRVCVEN [?]), najbardziej zaś wewnętrzne tłoczenia $\mathrm{z}$ ornamentami tralkowym i roślinnym. Pozostałą w zwierciadle oraz w powstałych listwach powierzchnię wzbogacają zdobienia wykonane radełkiem, prezentujące tzw. motyw palmetowo-arkadowy. Na podstawie radełka prezentującego reformatorów oprawę można przypisać niemieckiemu introligatorowi Johannowi von Sachsenowi działającemu w Marburgu ${ }^{96}$.

Bardziej dostojną formę oznaczania własnych ksiąg zastosował Karnkowski w pięciu przypadkach, umieszczając na powierzchni opraw superekslibrisy. Z okresem jego referendarstwa koronnego związany jest obszerny foliant zawierający urywek Digestów Justyniana (Florencja 1553). Obleczone w bordową skórę wzmocnioną tekturą okładziny reprezentują późny przykład italianizującej oprawy nawiązującej do typu aldyńsko-grolierowskiego ${ }^{97}$ pokrytej złoconymi tłoczeniami ${ }^{98}$. Całość utworzona została przez trzy podwójne kompozycje linearne w kształcie prostokąta, którego wnętrze dopełnione zostało czwartą, romboidalną ramką strychulcową. Wzbogacają je liczne wyciski arabeskowe i te o formach

95 Najprawdopodobniej znajdowały się tam następujące podpisy: MARTI; PHILIP; ERASM; $I O H A N$. Identyczne bowiem narzędzie posłużyło do wykonania oprawy druku znajdującego się w Staatliche Bibliothek w Ratyzbonie (zob. EBDB r003195).

96 Ibidem. Do wytworzenia oprawy introligator wykorzystał papier z filigranem rozpowszechniony w tym okresie od terenów nadreńskich po Lubekę i Hamburg (C.M. Briquet, Les Filigranes Dictionnaire Historique des Marques du Papier des Leur Apparition vers 1282 jusq'en 1600. Avec 39 figures dans le texte et 16,112 fac-similés de filigranes. T. 2, Ci-K, Genève 1907, $\mathrm{nr} 5315)$.

97 M. Czapnik, Księgozbiór Krzysztoporskich. Z dziejów renesansowych bibliotek szlacheckich, [w:] Kolekcje historyczne. Ksiegozbiory szlacheckie XVI-XVII wieku, t. 2, Warszawa 2009, s. 92; K. Opalińska, Szlachta różnowiercza i pozostałości po jej księgozbiorach w zbiorach BUW (XVI w.), [w:] Kolekcje historyczne..., s. 166-167; A. Wagner, Nieznana oprawa dla Jana Easkiego $w$ Bibliotece Uniwersyteckiej w Poznaniu. Przyczynek do badań nad italianizmem w introligatorstwie polskim XVI wieku, „Biblioteka” 2012, nr 16 (25), s. 26-31; idem, Oprawy ksiag Andrzeja Opalińskiego, [w:] Księgozbiór wielkopolskiego magnata: Andrzej Opaliński (1540-1593), pod red. idem, Poznań 2011, s. 149-153; idem, Włoskie wplywy w polskim introligatorstwie XV-XVI wieku, [w:] Tegumentologia polska dzisiaj, pod red. A. Wagnera, Toruń 2015, s. 96-102.

98 P. Pokora, M. Muraszko, Skarby drukarstwa i introligatorstwa ze zbiorów dawnej Biblioteki Katedralnej w Gnieźnie: katalog wystawy w Bibliotece Raczyńskich, Poznań 5-30 maja 2015, Poznań-Gniezno 2015, s. 17. Ten sam egzemplarz wzmiankuje także A. Wagner, Superekslibris polski: studium o kulturze bibliofilskiej i sztuce od średniowiecza do połowy XVII wieku, Toruń 2016, s. 173-174. 
kwiatonów i listków, jak również niewielkie półkola, umieszczone w wewnętrznych ramkach prostokątnych, ze zwróconymi ku sobie łukami. W centralnym punkcie oprawy wyciśnięto renesansowy ${ }^{99}$ superekslibris introligatorski (il. 1) złożony z tarczy z Ciołkiem w godle (zamiast Junoszy!) otoczonej okrągłym wieńcem laurowym $(80 \times 82 \mathrm{~mm})$. Całość okalają tłoczenia liternicze: $S($ TANISLAUS) K(ARNKOWSKI) // S(ACRAE) MA(IESTATIS) // RE(FERENDARIVS) CV(RIAE). Błąd związany z niewłaściwym w tym wypadku godłem złożyć należy najpewniej na karb introligatora ${ }^{100}$ działającego przypuszczalnie w Krakowie, na co wskazuje filigran grembienickiej papierni ${ }^{101}$.

Kolejny superekslibris (il. 2) pochodzący już z okresu arcybiskupiego, umieszczony na oprawie druku paryskiego z 1586 roku $^{102}$ wykonanej z pergaminu usztywnionego tekturą, stanowi nienotowany dotąd w literaturze wariant typu II (według typologii S. Rybandta) ${ }^{103}$. Sporządzony pierwotnie w czasie zasiadania na stolcu włocławskim (1564-1581) znak własnościowy na gnieźnieńskim egzemplarzu pojawia się w jego uaktualnionej wersji. Miejsce pastorału zajmuje teraz krzyż. Nieznacznej zmianie uległ także napis w obramieniu: STANISLAVS KARNKOWSKI D(EI): G(RATIA): ARCHIEPISCOPVS GNESNENSIS: Wiernie odwzorowane detale różnią się zasadniczo jedynie w układzie przewiązek. Zmianie nie uległ także rozmiar wycisku $(64 \times 54 \mathrm{~mm})$ odpowiadający wielkością pierwowzorowi.

Równie ciekawie jawi się superekslibris wyciśnięty na pergaminowej oprawie Messiasza Adriana Junga (Poznań, Barbara Wolrabowa i dziedzice 1597) ${ }^{104}$ (il. 3). Ten łudząco podobny do przykładu reprodukowanego przez S. Rybandta ${ }^{105}$ oraz M. Sipayłło ${ }^{106}$ różni się jednak w poszczególnych detalach, w sposób najbardziej

99 A. Wagner, Supralibros in Polen in der Zeit vom 15. bis zur ersten Hälfte des 17. Jahrhunderts im Lichte neuester Forschungen, „Einband Forschung” 34, 2014, s. 57-58; idem, Superekslibris..., s. 212-216.

100 Podobny przykład odnaleźć można na jednym z superekslibrisów Marii Kazimiery Sobieskiej - spowodowany jest on brakiem potrzebnych narzędzi we włoskim warsztacie introligatorskim (D. Sidorowicz-Mulak, Z królewskich księgozbiorów XVII-XVIII wieku. Oprawy z superekslibrisami polskich królów i królowych ze zbiorów Ossolineum, [w:] Tegumentologia polska dzisiaj..., s. 308). Wykluczyć nie można również sytuacji nabycia przez Karnkowskiego oprawionego woluminu z wytłoczonym już herbem. Sygle wskazujące na referendarza koronnego byłyby w tym przypadku późniejsze.

101 W. Budka, op. cit., nr 125, 126.

102 AAG, sygn. BK 6346.

103 S. Rybandt, Superekslibrisy..., s. 13-14; M. Sipayłło, Polskie superexlibrisy XVI-XVIII wieku w zbiorach Biblioteki Uniwersyteckiej w Warszawie, Warszawa 1988, tabl. 34; K. Rulka, Superekslibrisy w zbiorach Biblioteki Seminarium Duchownego we Włocławku, „Studia Włocławskie" 6, 2003, s. 529; Z. Skiełczyński, op. cit., s. 7.

104 AAG, sygn. PL 322. Identyczny superekslibris wytłoczony na woluminie spoczywającym w Seminarium Duchownym we Włocławku wzmiankuje A. Wagner (Superekslibris..., s. 481).

105 S. Rybandt, Superekslibrisy..., fot. 5.

106 M. Sipayłło, op. cit., tabl. 35. 


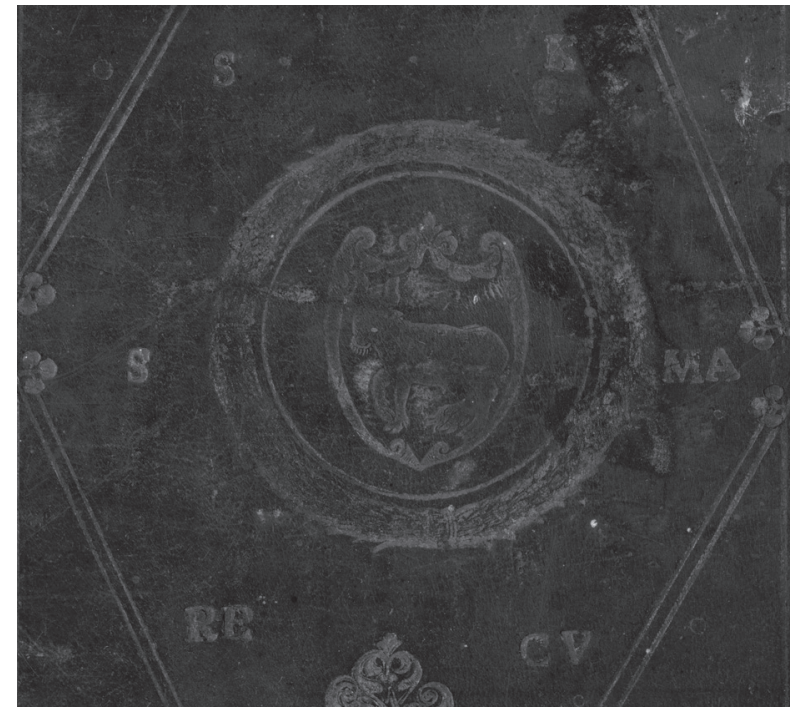

Il. 1. Superekslibris introligatorski (1558-1564). AAG, sygn. BKS 3294. Fot. M. Krobski

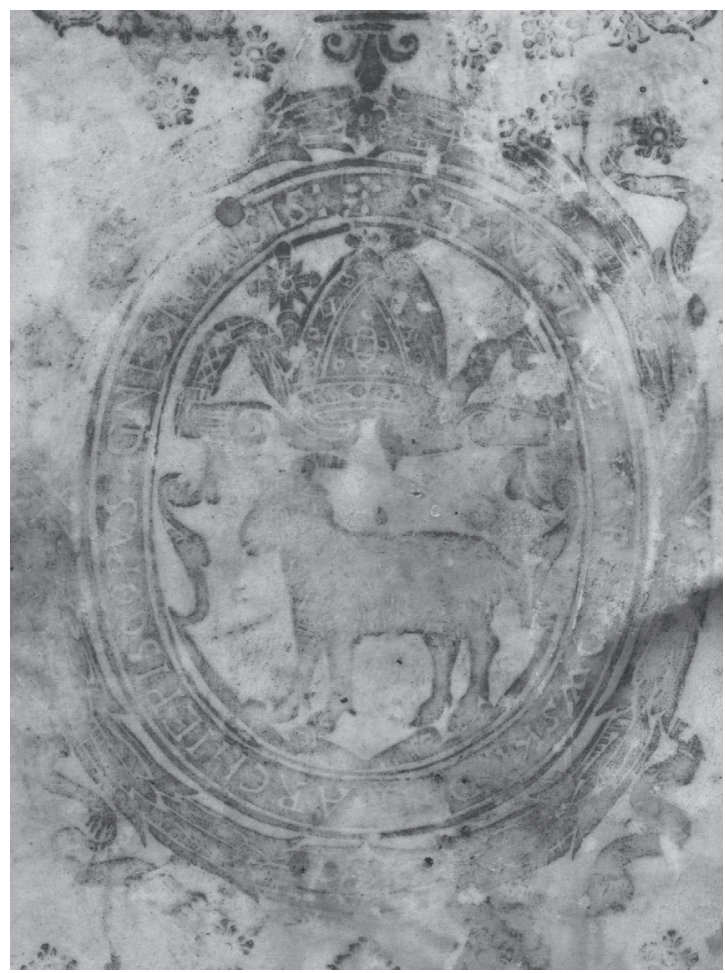

Il. 2. Superekslibris właściwy (1581-1603). AAG, sygn. BK 6346. Fot. M. Bartoszak 


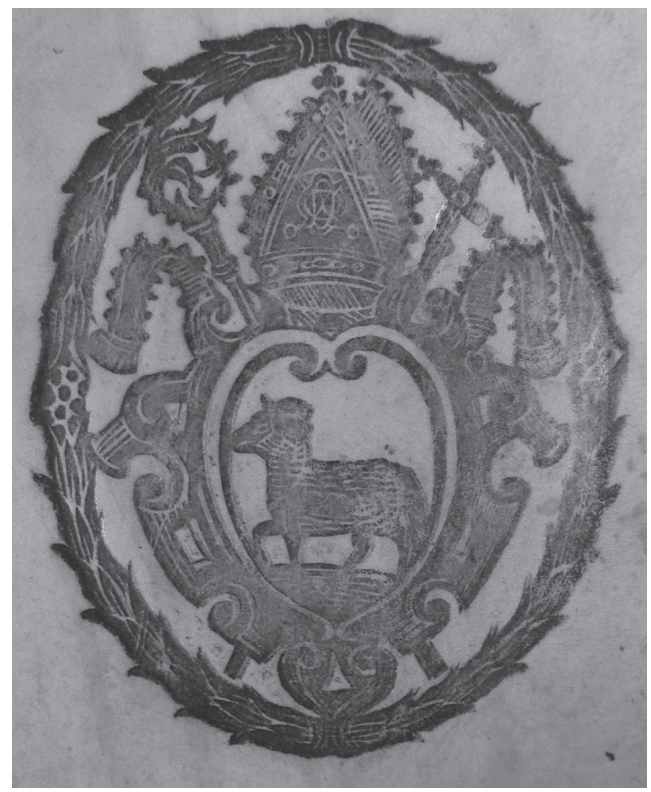

I1. 3. Superekslibris właściwy (1581-1603). AAG, sygn. PL 322. Fot. P. Pokora

widoczny natomiast $\mathrm{w}$ braku pastorału, obecnego z kolei na gnieźnieńskim egzemplarzu, czyniąc go zarazem jeszcze bardziej zbliżonym wizualnie do drzeworytu stosowanego przez oficynę Wolrabową w drukach z lat 1586 i $1593^{107}$. Oba tłoki i w tym wypadku nie są jednak tożsame. Zaskakująca zbieżność wykorzystywanego drzeworytu w dwóch wydaniach kazań prymasa z 1593 roku z zastosowanym narzędziem introligatorskim wytłoczonym na oprawie kryjącej dzieło Junga wydrukowane w tej samej oficynie sugeruje jakąś ingerencję typografa. Kusząca perspektywa wpisania tego znaku własnościowego w poczet superekslibrisów dedykacyjnych, wykonanego na polecenie Barbary Wolrabowej dla swojego najdostojniejszego klienta, rozbić się musi o konstatację pospolitszego wariantu wydania pozbawionego drzeworytu $z$ herbem Zygmunta III pojawiającego się na odwrocie karty tytułowej egzemplarzy przeznaczonych dla dygnitarzy ${ }^{108}$. Możliwe w tym wypadku jest uznanie go za rodzaj superekslibrisu nakładowego, prawie zupełnie w Polsce nieznanego ${ }^{109}$, lub (co bardziej prawdopodobne) za supereksli-

107 A. Chyczewska, Zasób drzeworytów ilustracyjnych i herbowych w XVI-wiecznych oficynach poznańskich, [w:] Z zagadnień teorii i praktyki bibliotekarskiej. Studia poświęcone pamięci Józefa Grycza, Wrocław-Warszawa-Kraków 1961, s. 367-368.

108 A. Kawecka-Gryczowa, Barbara Wolrabowa i dziedzice 1592-1602, [w:] Drukarze dawnej Polski. T. 3, Od XIV do XVIII wieku. Cz. 1, Wielkopolska, oprac. A. Kawecka-Gryczowa, K. Korotajowa, J. Sójka, Wrocław 1977, s. 281.

109 M. Cubrzyńska-Leonarczyk, Polskie superekslibrisy, Warszawa 2001, s. 9-10; A. Wagner, Superekslibris..., s. 55. 
bris donacyjny arcybiskupa. W tym ostatnim przypadku można by zaryzykować hipotezę o nabyciu druku i opatrzeniu go swoim znakiem własnościowym z zamiarem podarowania go innemu hierarsze - biskupowi płockiemu Wojciechowi Baranowskiemu, o czym informuje odręczny wpis wewnątrz woluminu ${ }^{110}$.

Ostatnią formę introligatorskiego sposobu oznaczania własności ksiąg stanowi superekslibris typu V w wariancie II (według typologii S. Rybandta) ${ }^{111}$. Stosowany w okresie arcybiskupim (1581-1603) znak własnościowy umieszczony został na dwóch woluminach. Pierwszy z nich zawiera dwa początkowe tomy dzieła Vazqueza Menchacy (Wenecja 1595) ${ }^{112}$ oprawione w pergamin na tekturze, w którego dłuższych krawędziach zastosowano rzemienne wiązania. Pokryta złoconymi tłoczeniami powierzchnia okładzin tworzy kompozycję ramową złożoną z zewnętrznej podwójnej ramki strychulcowej oraz powstałej przy użyciu radełka wewnętrznej plecionkowej, urozmaiconą dodatkowo dwoma rodzajami wycisków w formie kwiatu maku, ulokowanymi w rogach zwierciadła i narożnikach pola utworzonego przez ramki. W centrum górnej okładziny wyciśnięto natomiast plakietę z owalnym medalionem z wizerunkiem Chrystusa Salwatora w podwójnym obramieniu: napisowym i ornamentalnym, na dolnej natomiast wspomniany superekslibris właściciela. Pozbawiony zwięzów płaski grzbiet zdobi dodatkowo kaligraficzne pismo o kroju rotundy. Papier pochodzący z Murowanej Gośliny sugeruje poznańską proweniencję rzemieślniczą oprawy ${ }^{113}$.

Drugim woluminem zawierającym ten typ superekslibrisu właściwego jest książka z komentarzami Azpilcuety (Wenecja 1588) ${ }^{114}$. Powleczona pergaminem oprawa pokryta jest złotymi wyciskami tworzącymi podwójną kompozycję ramową, z których zewnętrzną wypełnia wić roślinna, wewnętrzną zaś plecionka sznurowa. Wizualny aspekt wzbogacają również liczne wyciski w formie kwiatonów. Na tym woluminie za właściwe miejsce dla znaku własnościowego posesora uznano centrum górnej okładziny, dla dolnej natomiast plakietę z przedstawie-

110 AAG, sygn. PL 322, k. a $\mathrm{a}_{[1] \mathrm{r}}, I E(G) O: M(O S ́ C I)$. X(iędzu). Biskupowi Ploczkiemu Autor $D(a t)$.

111 S. Rybandt, Superekslibrisy..., fot. 8. Ponadto u: T. Moskal, Książki z superekslibrisami biskupów polskich okresu przedrozbiorowego w Bibliotece Diecezjalnej w Sandomierzu, [w:] Artem historicam aliis tradere. Księga pamiatkowa ku czci Księdza Profesora Anzelma Weissa, Lublin 2011, s. 197-198; K. Rulka, Superekslibrisy..., s. 530; M. Sipayłło, op. cit., tabl. 38.

112 AAG, sygn. BK 845.

113 W. Budka, op. cit., nr 258; S. Żurowski, Znaki wodne papiernictwa wielkopolskiego XVI$X I X$ w., „Zeszyty Naukowe Uniwersytetu im. Adama Mickiewicza w Poznaniu. Biblioteka” 5/57, 1965, nr 12. Warta uwagi wydaje się identyczność zastosowanych narzędzi i założenia kompozycyjnego oprawy z tą posiadaną przez kanonika gnieźnieńskiego Leonarda Walkonowskiego (AA Gn, sygn. BK 2894). W tym jednak przypadku papier dostarczony został przypuszczalnie z krajów niemieckich (R. Franczak, Pozostałości księgozbioru kanonika gnieźnieńskiego Leonarda Walkonowskiego w zasobie Archiwum Archidiecezjalnego w Gnieźnie, „Archiwista Polski” 2014, nr 3, s. 35-36).

114 AAG, sygn. BK 1478. 
niem Grupy Ukrzyżowania. Niezidentyfikowany pozostaje użyty przez introligatora papier $\mathrm{z}$ filigranem prezentującym kartusz z tarczą z herbem Poraj otoczony hełmem i bujnymi labrami.

Obok tego sposobu oznaczania własnych ksiąg Karnkowski posługiwał się w okresie prymasowskim (1581-1603) wzmiankowaną co najmniej kilkukrotnie w literaturze ${ }^{115}$ pieczęcią odciskaną bezpośrednio na kartach woluminów. Spośród omawianych egzemplarzy taki znak, wykazujący jednolite wymiary $48 / 49 \times 30 / 31 \mathrm{~mm}$, odnaleźć można w 25 woluminach $^{116}$. Fakt zdublowania w sześciu przypadkach ${ }^{117}$ innymi formami księgoznaków połączony z brakiem pieczęci w trzech woluminach ${ }^{118}$, nabytych najprawdopodobniej pod koniec życia drugiego interreksa, sugerować może ostateczne zużycie się uszkodzonego klocka w końcowym okresie, którego naniesienie związane było, być może, z jakąś działalnością kontrolną (czy inwentaryzacyjną) księgozbioru. Zagadnienie to wymaga jednak dokonania porównań na zdecydowanie zasobniejszym zbiorze. Kształt i forma tego znaku własnościowego zbliżonego do odcisków pieczętnych sensu stricto skłania do uważniejszego przyrównania obu tych znaków identyfikacyjnych prymasa. Stwierdzić jednak należy, że obie te formy nie wykazują niestety żadnych analogii kompozycyjnych ${ }^{119}$.

Kierunki rozchodzenia się księgozbioru rozbić można na te przekazane za życia prymasa oraz przejęte po jego śmierci. Do pierwszej grupy zaliczyć można trzy księgi. Znana hojność arcybiskupa dla kolegium poznańskich jezuitów zamanifestowała się również w darze książkowym z 1583 (lub 1585) $)^{120}$. Z tamtego czasu pochodzą zapewne odręczne wpisy w dwóch księgach Inscriptus catalogo

115 E. Chwalewik, Exlibrisy polskie szesnastego i siedemnastego wieku, Wrocław 1955, il. 12, s. 34-35; S. Rybandt, Księgozbiór..., s. 122; A. Wagner, Uwagi o znakach własnościowych $z$ drugiej połowy XV i pierwszej ćwierci XVI wieku w inkunabułach Biblioteki Uniwersyteckiej w Poznaniu, „Biblioteka” 2013, nr 17 (26), s. 32-33.

116 AAG, sygn.: BK 249, BK 725, BK 762, BK 897, BK 905, BK 944, BK 964, BK 965, BK 966, BK 1048, BK 1364, BK 1478, BK 1566, BK 6043, BK 6088, BK 6476, BK 11074, BKS 745, BKS 1196, BKS 3294, BKS 5251, Inc. 321, Inc. 655, PL 69, PL 108b. Dodać do tego należy dwa dalsze egzemplarze w zespołach Archiwum Archidiecezjalnego w Gnieźnie. Jeden odcisk pieczęci Stanisława Karnkowskiego zachowany jest w zbiorze ekslibrisów ks. Leona Formanowicza (nr 304) na wyciętym fragmencie ze starodruku. Drugą wyciśnięto z kolei na jednej z ksiąg kapituły gnieźnieńskiej (ACap GVII 16, k. 1r).

117 AAG, sygn.: BK 1364, BK 1478, BK 1566, BK 6043, BKS 1196, BKS 3294.

118 AAG, sygn.: BK 845, BK 6346, PL 322.

119 AAG, zbiór odlewów gipsowych pieczęci ks. Leona Formanowicza.

120 R. Witkowski, O najstarszej bibliotece poznańskich jezuitów $w$ świetle zachowanych w Szwecji katalogów bibliotecznych, „Kronika Miasta Poznania” 1997, nr 4, s. 126. Ponadto zob. Kronika jezuitów poznańskich (młodsza). T. 1, 1570-1653, oprac. L. Grzebień, J. Wiesiołowski, tłum. K. Kaczor, Poznań 2004, s. 149; R. Witkowski, Biblioteka jezuicka katalogów z poczatku XVII wieku, [w:] Wokół jezuickiej fundacji uniwersytetu z 1611 roku, pod red. D. Żołądź-Strzelczyk, R. Witkowskiego, Poznań 2011, s. 180. 
Collegij Posnan(iensis) ${ }^{121}$. Dalsza droga tych woluminów, znana jedynie w przypadku egzemplarza o sygn. BKS 745, wiedzie przez klasztor bernardynów w Górce Klasztornej k. Łobżenicy. Z tego okresu wędrówki woluminu pochodzi prawdopodobnie nota z 1663 roku tamtejszego gwardianina Franciszka Mollera ${ }^{122}$ oraz prawdopodobnie późniejsza - samego klasztoru ${ }^{123}$, założonego dopiero w 1636 roku. Przypuścić jedynie można, że pewne dary książkowe przekazane być mogły w wyniku grabieży dokonanych przez wojska szwedzkie w $1657 \mathrm{roku}^{124}$.

Indy widualną donacją był natomiast wspomniany dar dla ówczesnego biskupa płockiego, a później arcybiskupa gnieźnieńskiego - Wojciecha Baranowskiego ${ }^{125}$.

Trudne do umiejscowienia w czasie przejście dwóch książek w ręce opata lubińskiego Jakuba Łempickiego ${ }^{126}$ mogło nastąpić za życia Karnkowskiego w formie darów dla zaufanego współpracownika ${ }^{127}$. Ale mogły też przejść w niewyjaśnionych okolicznościach do jego księgozbioru dopiero po śmierci protektora. Równie problematyczne wydają się woluminy z wpisami Wojciecha Bagińskiego, kanonika uniejowskiego i plebana konińskiego ${ }^{128}$, zmarłego przed 1618 rokiem $^{129}$, a także Kacpra Hączela Mokrskiego (zm. 1648), którego wpis występuje obok noty własnościowej bliżej nieokreślonego kościoła w Nowym Mieście (?) ${ }^{130}$.

Znaczna część (16) ksiąg ${ }^{131}$ zawiera kaligrafowane wpisy archidiakona gnieźnieńskiego oraz doktora obojga praw Wincentego de Sevé (zm. 1611). Niemożność wskazania czasu przejścia tych woluminów do księgozbioru prałata zmusza do stawiania hipotez. Przejście dużej liczby karnkovianów w inne ręce po śmierci prymasa poza jego zapisem testamentowym ${ }^{132}$ wydaje się mało prawdopodob-

121 AAG, sygn.: BKS 745, Inc. 321.

122 AAG, sygn. BS 745, Franciscu Moller Ordinis S Francisci de Obser(v)a(nt)ia Ind[...]

orum [?] reliquet p(ro) loco Lobsinensi Guardian(us) p(ro) tunc eiusdem loci 1663.

123 Ibidem, Con(ven)t(us) Gorcensis Ad Sancta V(irginis)M(ariae):

124 G. Kamiński, P. Krupa, Górka Klasztorna, Pelplin 2013, s. 20.

125 O zawiłych losach testamentowego legatu Wojciecha Baranowskiego wspomina J. Rył, Biblioteka Katedralna w Gnieźnie, „Archiwa, Biblioteki i Muzea Kościelne” 32, 1976, s. 75.

126 AAG, sygn.: BKS 5251, BKS 6346.

127 Zob. s. 46.

128 AAG, sygn. PL 108b, Albertus Bagiński C(anonicus) V(nieioviensis) P(lebanus) Koninesis.

129 Teki Dworzaczka: regesty, Grodzkie i Ziemskie — Konin, 6922 (nr 40) 1618.

130 AAG, sygn. PL 69, Gaspari Haczel Mokrski Canonici Posnaniensis oraz Sum Ecclesie Nowomestensis. Mokrski zainstalowany został na kanonię w 1637 roku, zmarł natomiast w roku 1648 (L. Formanowicz, op. cit., nr 200).

131 AAG, sygn.: BK 249, BK 725, BK 762, BK 845, BK 897, BK 944, BK 964, BK 965, BK 966, BK 1048, BK 1364, BK 1566, BK 6043, BK 6088, BKS 1196, BKS 3294.

${ }^{132}$ AAG, sygn. A Cap luzy C4, nr 3. Legatem testamentowym zasadnicze zręby księgozbioru przeszły do kaliskiego kolegium jezuitów (k. [3r]: mszał rzymski pokryty czerwonym aksamitem z puklami srebrnemi złocistemi y klauzurami; wszystkie książki teologiczne i historyczne quibus sua R(everendissi)ma P(aterni)tas utitur, et in Bibliotheca sua Lovicy, vel in suo hypocausto et alibi reperientur), biskupa kujawskiego Jana Tarnowskiego (k. [3v]: Musicalia cum libris 
ne. Przyjąć zatem należy ich stopniowe przekazywanie przez prymasa $\mathrm{w}$ formie darów bądź poprzez wymianę między prymasem a jego bliskim współpracownikiem realizującym dla niego szereg misji zagranicznych i krajowych ${ }^{133}$.

Podkreślenia wymagają pojawiające się na grzbietach woluminów posiadanych przez archidiakona rzadkie na gruncie polskim napisy o kroju rotundy w typie hiszpańskim biegnące równolegle do grzbietu ${ }^{134}$. Inicjatywę ich wykonania przypisać należy najpewniej Wincentemu de Sevé, o czym przekonują w pierwszej kolejności pojawiające się u niego napisy gotyckie. Jedyne odstępstwo zachodzi przy woluminie nr PL 322, stanowiącym podarek Karnkowskiego dla Wojciecha Baranowskiego - następcy Piotra Dunina-Wolskiego na biskupstwie płockim ${ }^{135}$, i to raczej z Baranowskim prędzej należałoby powiązać ów sposób zdobienia grzbietu. Ponadto wyłącznie w przejętych przez Wincentego książkach pojawiają się oprawy wytworzone w warsztacie pruskim (prawdopodobnie gdańskim), na co wskazuje widoczny filigran podgdańskiej papierni Probstlów zbliżony do formy z ok. 1600 roku $^{136}$, na których każdorazowo pojawia się napis w typie hiszpańskim. Powstałe zatem staraniem archidiakona oprawy zawsze miały pierwotnie naniesiony ten właśnie napis.

Omówienia wymaga jeszcze pięć ksiąg noszących wyłącznie znaki pozwalające je przypisać do bibliotek Karnkowskiego i seminarium duchownego w Gnieźnie ${ }^{137}$. Ufundowana w 1602 roku z inicjatywy prymasa placówka ${ }^{138}$ przygotowująca kleryków do posługi kościelnej nie doczekała się żadnych zapisów testamentowych ani znanych przekazów książkowych. Trudna do sprecyzowania droga przejścia tych woluminów do seminarium rozwiązanie znaleźć może w uznaniu ich za drobne podarki dla nowo ufundowanej placówki. Kwestia ta daleka jest jednak od rozstrzygnięcia.

Wzbogacenie zatem księgozbioru o nieznane wcześniej zidentyfikowane w Archiwum Archidiecezjalnym w Gnieźnie 22 księgi, należące niegdyś do prymasa i zarazem bibliofila Stanisława Karnkowskiego, pozwala podnieść wymiar

impressis ex allatis et allys etiam Musicalibus, manuscript(is) et annotat(is). Ite(m) Libros o(mn) es manuscriptos et scripturas o(mn)es quas habet ut asseuit in quibusdam capsis in Bibliothecae sua inclusas) oraz dziekana gnieźnieńskiego Marcina Karnkowskiego (k. [3v]: wszystkie książki prawnicze, qui t(em)p(o)re mort(e) Testatoris sup(rascrip)ti in Bibliotheca reperie $(n) t(u) r)$.

133 J. Korytkowski, Prałaci, t. 3, Gniezno 1883, s. 463-474, wspomina o przyjaźni łączącej duchownych. Drogę przejścia księgozbioru Wincentego wyjaśnia J. Rył, op. cit., s. 77.

134 Jedynym znanym chyba przykładem stosowania podobnych napisów grzbietowych w Polsce jest księgozbiór biskupa płockiego Piotra Dunina-Wolskiego (K. Piekarski, Odkrycie „Volsciany” w zbiorach Bibljoteki Jagiellońskiej, [w:] Bibljoteka Piotra Wolskiego biskupa płockiego, Kraków 1929, s. 14-15).

135 A. Strzelecki, Baranowski Wojciech, [w:] PSB, t. 1, Kraków 1935, s. 287-288.

136 J. Siniarska-Czaplicka, op. cit., nr 1265; eadem, Papier druków oficyn gdańskich i toruńskich, „Roczniki Biblioteczne” 18, 1974, z. 1-2, s. 288-289.

137 AAG, sygn.: BK 905, BK 1478, BK 6476, BK 11074, Inc. 655.

138 AAG, Dypl. Gn., sygn. 860. 
liczbowy jego dotąd przebadanej części do przynajmniej 356 woluminów ${ }^{139}$, sam natomiast zasób karnkovianów gnieźnieńskiego Archiwum wywindować na drugie miejsce pod względem zasobności pozostałych po prymasie ksiąg z jego librarii (w sumie 28$)^{140}$.

Zapowiadana przez S. Rybandta kompleksowa praca o księgozbiorze tego zasłużonego hierarchy nie doczekała się jak na razie swojej realizacji. Kolejne odkrywane woluminy wskazywać mogą nie w pełni jeszcze zbadane przypuszczalne miejsca, w jakich znaleźć można następne karnkoviana, zmuszając zarazem do dalszych poszukiwań.

ANEKS

KATALOG DRUKÓW Z KSIĘGOZBIORU PRYMASA S. KARNKOWSKIEGO

\section{Afflitto Matteo d'}

In utriusque Siciliae, Neapoliq(ue) sanctiones, et constitutiones novissima praelectio. Prima pars super primum librum. Interiecta sunt Ioannis Antonij Batij, et aliorum erudita adnotamenta [...].

Venetiis: [s.n.] $1562 ; 2^{\circ}$.

EDIT16 (online; CNCE 15840).

Prow.: 1. Stanisław Karnkowski - pieczęć.

2. Ex libris Adm[...] Vincenti de Seve I(uris).V(triusve).D(octoris). Lascen(sis) [...] (wyrwane).

3. Ex R(evere)nd(issi)mi Capituli Gne[...] (wyrwane).

4. Archiwum Archidiecezjalne w Poznaniu - pieczątka.

Oprawa: tektura, pergamin, tkane wiązania; warsztat gdański (?).

\section{Azpilcueta Martin}

AAG, sygn. BK 6088

Commentaria Et Tractatus Hucusque Editi, atque nunc recens in unum collecti [...] et in tres tomos distincti.

Venetiis: Damianus Zenarius, $1588 ; 2^{\circ}$.

EDIT16 (online; CNCE 3738).

Prow.: 1. Stanisław Karnkowski - superekslibris: typ V, wariant II (górna okładzina) oraz pieczęć.

2. Inscriptus catalogo librorum Seminarij Eccl[esi]ae Metropol(ita) nae Gnesn(ensis).

Oprawa: tektura, pergamin, tłocz. złoc.

AAG, sygn. BK 1478

139 S. Rybandt, Księgozbiór..., s. 121-124.

140 T. Moskal, Książki z superekslibrisami..., s. 197-198; K. Rulka, Personalne..., s. 363364; S. Rybandt, Księgozbiór..., s. 121-122. 


\section{3. Éguiner Baron}

Ad Obertum Ortensium, de Beneficiis, Commentarii, Methodo in eundem subiecti.

Lugduni: Sebastianus Gryphius, 1549; $4^{\circ}$.

ICCU (online); KVK (online).

Prow.: 1. Stanisław Karnkowski - pieczęć.

2. Ex Libr(is). Admod(um). R(evere)ndi. D(omini). Vincentii de Seue I(uris). V(triusque). D(octoris). Lascen(sis). et Louicien(sis). Praepo(si)ti. Archidiaconi. Gnesnen(sis).

3. R(evere)nd(issi)mi Capituli Gnesnens(sis).

Oprawa: tektura, pergamin, rzemienne wiązania.

\section{Bartolus de Saxoferrato}

AAG, sygn. BK 762

Commentaria In Primam [-Secundam] Digesti Novi partem, doctiss. viri D. Petri Pauli Parisii Cardinalis admodum reverendi, non paucis additionibus nuper illustrata, accurateque castigata.

Lugduni: Dionysius Harsaeus, $1550 ; 2^{\circ}$.

ICCU (online); KVK (online).

Prow.: 1. Stanisław Karnkowski — pieczęć.

2. Ex Libr(is). Admod(um). R(evere)ndi. D(omini). Vincentii de Seue I(uris). V(triusque). D(octoris). Lascen(sis). et Louicien(sis). Praepo(si)ti. Archidiaconi. Gnesnen(sis).

3. Ex Bibliotheca R(evere)nd(issi)mi Capituli Gnesnen(sis).

Oprawa: tektura, pergamin, tłocz. złoc., tkane wiązania; warsztat gdański (?).

\section{Bartolus de Saxoferrato}

AAG, sygn. BK 966

Commentaria In Primam [-Secundam] Digesti veteris parte(m) doctiss. viri D. Petri Pauli Parisii Cardinalis admodum reuerendi non paucis additionibus nuper illustrata, accurateque castigata.

ICCU (online); KVK (online).

Lugduni: Dionysius Harsaeus, 1550; $2^{\circ}$.

Prow.: 1. Stanisław Karnkowski - pieczęć.

2. Ex Libr(is). Admod(um). R(evere)ndi. D(omini). Vincentii de Seue I(uris). V(triusque). D(octoris). Lascen(sis). et Louicien(sis). Praepo(si)ti. Archidiaconi. Gnesnen(sis).

3. Ex Bibliotheca R(evere)nd(issi)mi Capituli Gnesnen(sis).

Oprawa: tektura, pergamin, tłocz. złoc., tkane wiązania; warsztat gdański (?).

\section{Bartolus de Saxoferrato}

AAG, sygn. BK 944

Commentaria In Primam [-Secundam] Infortiati partem doctiss. viri Do. Petri Pauli Parisij Cardinalis admodum reuerendi non paucis additionibus nuper illustrata, accurateque castigata. 
ICCU (online); KVK (online).

Lugduni: Dionysius Harsaeus, 1550; $2^{\circ}$.

Prow.: 1. Stanisław Karnkowski - pieczęć.

2. Ex Libr(is). Admod(um). R(evere)ndi. D(omini). Vincentii de Seue I(uris). V(triusque). D(octoris). Lascen(sis). et Louicien(sis). Praepo(si)ti. Archidiaconi. Gnesnen(sis).

3. Ex Bibliotheca R(evere)nd(issi)mi Capituli Gnesnen(sis).

Oprawa: tektura, pergamin, tłocz. złoc., tkane wiązania; warsztat gdański (?). AAG, sygn. BK 964

\section{Bartolus de Saxoferrato}

Commentaria In Tres Libros Codicis, doctissimi viri Do. Petri Pauli Parisii Cardinalis admodum reverendi non paucis additionibus nuper illustrata, accurateque castigata.

Lugduni: [Dionysius Harsaeus], 1549; $2^{\circ}$.

ICCU (online); KVK (online).

Prow.: 1. Stanisław Karnkowski - pieczęć.

2. Ex Libr(is). Admod(um). R(evere)ndi. D(omini). Vincentii de Seue I(uris). V(triusque). D(octoris). Lascen(sis). et Louicien(sis). Praepo(si)ti. Archidiaconi. Gnesnen(sis).

3. Ex Bibliotheca R(evere)nd(issi)mi Capituli Gnesnen(sis).

Oprawa: tektura, pergamin, tłocz. złoc., tkane wiązania; warsztat gdański (?).

AAG, sygn. BK 965

\section{Bartolus de Saxoferrato}

Commentaria Super Authenticis, doctissimi viri Domini Petri Pauli Parisij Cardinalis admodum reverendi, non paucis additionibus nuper illustrata, accurateque castigata.

ICCU (online); KVK (online).

Lugduni: Dionysius Harsaeus, $1549 ; 2^{\circ}$.

Prow. i opr. zob. poz. 7.

\section{Bartolus de Saxoferrato}

AAG, sygn. BK 965

Consilia Quaestiones, Et Tractatus [...], nunc diligentiori cura quam antehac castigati, (et) in suum pristinum splendore[m] feliciter restituti.

Lugduni: Dionysius Harsaeus, 1550; $2^{\circ}$.

ICCU (online); KVK (online).

Prow. i opr. zob. poz. 7.

\section{Bartolus de Saxoferrato}

AAG, sygn. BK 965

Index Sive Repertorium Singulare in lecturas Bartoli a Saxo in omne ius civile locupletissimum, nunc solerti cura, studiose, ac commode recognitum.

Lugduni: [Dionysius Harsaeus], 1550; $2^{\circ}$.

ICCU (online); KVK (online). 
Prow. i opr. zob. poz. 7.

\section{Botero Giovanni; Borromei Carlo S.}

AAG, sygn. BK 965

Ioan. Boteri Benensis Epistolarum Illustrissimi ac Reuerendissimi D. D. Caroli Cardinalis Borromaei nomine scriptarum. Libri II.

Parisiis: Thoma Perier, $1586 ; 12^{\circ}$.

ICCU (online).

Prow.: 1. Stanisław Karnkowski - superekslibris: typ II, wariant II.

2. Iacob(us) Lempicki Ab(bas) lub(inensis).

3. Conuentus Lubinensis Ord(inis). S(ancti). Bene(dicti).

Oprawa: tektura, pergamin, tłocz. złoc., tkane wiązania.

\section{Cagnolo Girolamo}

AAG, sygn. BK 6346

Constitutiones et leges primi, secundi, quinti, et duodecimi Pandectarum aurearum enarrationum liber primus. Tomus primus [-secundus].

Venetiis: Hieronymus Scotus, 1549; $4^{\circ}$.

EDIT16 (online; CNCE 8315).

Prow.: 1. Stanislai Karnkowski (nazwisko niemal wydrapane z karty).

2. Stanisław Karnkowski - pieczęć.

3. Ex Libr(is). Admod(um). R(evere)ndi. D(omini). Vincentii de Seue I(uris). V(triusque). D(octoris). Lascen(sis). et Louicien(sis). Praepo(si)ti. Archidiaconi. Gnesnen(sis).

4. Ex Bibliotheca R(evere)ndi(ssi)mi Capituli Metropolitani Gnesnensi oraz R(evere)nd(issi)mi Capituli Gnesnen(sis).

Oprawa: tektura, pergamin, tkane wiązania; warsztat poznański (?).

AAG, sygn. BK 1566

\section{Caravita Prospero}

Commentaria super ritibus magnae Curiae Vicariae regni Neapolis [...] Accesserunt etiam commentarii eximiorum iureconsultorum d. Anibalis Troysii Cavensis alias impressi, ac demum recogniti et emendati. Nec non (et) Ioannis Francisci Scaglioni super eisdem ritibus.

Venetiis: Marcus de Maria Salernitanus, 1563; $2^{\circ}$.

EDIT16 (online; CNCE 9360).

Prow.: 1. Stanisław Karnkowski - pieczęć.

2. Ex Libr(is). Admod(um). R(evere)ndi. D(omini). Vincentii de Seue I(uris). V(triusque). D(octoris). Lascen(sis). et Louicien(sis). Praepo(si)ti. Archidiaconi. Gnesnen(sis).

3. Ex Bibliotheca R(evere)ndi(ssi)mi Capituli Metropolitani Gnesnensi.

Oprawa: tektura, pergamin, tkane wiązania; warsztat gdański (?).

AAG, sygn. BK 897 


\section{Cauzio Camillo}

Scholia Pro Religione. In quibus agitur, De imagine Dei, De homine, Et Angelis, De lege Dei, De natura humana, De pietate hominis, De persona Christi.

Venetiis: Franciscu Laurentius, 1559; $8^{\circ}$.

EDIT16 (online; CNCE 10375).

Prow.: 1. Valentinus Cusborski [...] (nieczytelny).

2. $a[\ldots] p[\ldots] s p[\ldots]$ (wpis nieczytelny z powodu odbicia na nim pieczęci Stanisława Karnkowskiego).

3. Stanisław Karnkowski - pieczęć.

4. Iacob(us) Lempicki Ab(bas) lub(inensis).

Oprawa: tektura, pergamin, rzemienne wiązania.

\section{5. [Constitutiones synodales]}

AAG, sygn. BKS 5251

Constitutiones et decreta Condita In provincialii Synodo Mediolanense Quinta. Quam [...] Carolus episcopus Mediolani habuit, Anno M. D. L. XXIX. Gregorio XIII. Pont. Max.

Mediolani: typographia seminarii, $1580 ; 8^{\circ}$.

EDIT16 (online; CNCE 35194).

Prow.: 1. Stanisław Karnkowski — pieczęć.

2. Ex Libr(is). Admod(um). R(evere)ndi. D(omini). Vincentii de Seue I(uris). V(triusque). D(octoris). Lascen(sis). et Louicien(sis). Praepo(si)ti. Archidiaconi. Gnesnen(sis).

3. R(evere)nd(issi)mi Capituli Gnesnen(sis).

Oprawa: tektura, czarna skóra, tłocz. złoc. na grzbiecie.

\section{6. [Corpus Iuris Canonici - Decretalia]}

AAG, sygn. BK 249

Decretalium copiosum argumentum [...]. Divisiones glosarum ex Johannis Andrea Novella diligenter deprompte [...] Tabula Ludovici Belegnini, [...] Elimata Margarita Decretalium [...] annectitur [...] Carminibus habes aptatam presenti volumine interpretationem singularem [...].

Parisiae: Bertholdus Rembolt, 1510; $2^{\circ}$.

KVK (online).

Prow.: 1. Stanisław Karnkowski — pieczęć (odciśnięta dwukrotnie na k. ochronnej przedniej i s. tyt.).

2. Inscriptus catalogo libror(um). Seminarij Eccl(esi)ae Metropol(ita) nae Gnesnen(sis). Congreg(ationis) Missionis.

Oprawa: deska, brązowa skóra, tłocz. ślepe.

\section{7. [Corpus Iuris Civilis - Digesta]}

AAG, sygn. BK 6476

Digestorvm sev Pandectarvm libri qvinqvaginta ex florentinis Pandectis repraesentati [cz. 2]. 
Florentiae: Laurentius Torrentinus, $1553 ; 2^{\circ}$.

EDIT16 (online; CNCE 13438).

Prow.: 1. Stanisław Karnkowski - superekslibris z tarczą z Ciołkiem [!] (zamiast Junoszą) w okrągłym wieńcu laurowym i sygle: S(TANISLAUS) K(ARNKOWSKI) // S(ACRAE) MA(IESTATIS) // RE(FERENDARIVS) CV(RIAE).

2. Inscriptus catalogo libror(um) Seminarij Ecclesiae Metrop(olitanae) Gnesn(ensis).

Oprawa: tektura, bordowa skóra, tłocz. złoc.; warsztat krakowski (?).

18. [Corpus Iuris Civilis - Novellae, lac.-greckie]

AAG, sygn. BKS 3294

Nearōn Ioustinianou basileōs, tōn en tō. nyn heuriskomenōn, kai ōs euriskontai, biblion [...] Novellarum constitutionum Dn. Iustiniani principis, quae exstant, et ut exstant volumen. Appositi sunt item Canones sanctorum Apostolorum per Clementem in unum congesti. Gregorio Haloandro interprete [...].

Norimbergae: Iohannes Petreius, 1531; $2^{\circ}$.

VD16 C 5261.

Prow.: 1. Superekslibris z herbem Poraj i syglami S(TANISLAUS) D(AMBROWSKI) oraz Stani(laus) Dambrowski.

2. Stanisław Karnkowski - pieczęć.

3. Inscriptus catalogo libror(um). Seminarij Eccl(esi)ae Metropol(ita) nae Gnesnen(sis). Congreg(ationis). Missionis.

Oprawa: tektura, czarna skóra, tłocz. złoc.; warsztat krakowski (?).

\section{Corti Franceschino}

AAG, sygn. BK 905

Consilia [...] pro prima [-secunda] parte Consilia, nunc primum panduntur. Vna cum [...] repertorio: alphabetica serie: curiose congesto [...] Quibus addita sunt summaria [...].

Lugduni: Iacobus Giunta, 1543; $2^{\circ}$.

ICCU (online); KVK (online).

Prow. i opr. zob. poz. 31.

AAG, sygn. BK 1364

\section{Corti Franceschino}

Consilia [...] hac in sculptione novissima curiose repurgata: egregiis cuiuslibet consilii Frontispitio numeratim appositis praepositoque familiari [...] alphabeticoque repertorio [...].

Lugduni: Franciscus et Claudius Marchant, 1547; $2^{\circ}$.

ICCU (online); KVK (online).

Prow. i opr. zob. poz. 31. 


\section{Decio Filippo}

Super Decretalibus Luculentus, atque Memoria Nostra colendus, Prudentissimi, Utraque censura [...].

Lugduni: Iacobus Berion, 1544; $2^{\circ}$.

ICCU (online); KVK (online).

Prow.: 1. Stanislai Karnkowski oraz pieczęć.

2. Ex Libr(is). Admod(um). R(evere)ndi. D(omini). Vincentii de Seue I(uris). V(triusque). D(octoris). Lascen(sis). et Louicien(sis). Praepo(si)ti. Archidiaconi. Gnesnen(sis).

3. Ex Bibliotheca R(evere)nd(issi)mi Capituli Gnesnen(sis).

Oprawa: tektura, pergamin, tkane wiązania, napis gotycki na grzbiecie; warsztat gdański (?).

\section{Depulsio}

AAG, sygn. BK 6043

Depulsio calumniarum, quibus Athanasius [i. e. Pietro Paulo Vergerio] quidam in epistola, [et] alii nonnuli, cardinalem insectantur: cum explicatione duarum sententiarum de Eucharistia [...].

Dillingen: Sebald Mayer, $1559 ; 8^{\circ}$.

VD16 D 585.

Prow. i opr. zob. poz. 14.

\section{Federici Stefano}

AAG, sygn. BKS 5251

De Interpretatione Iuris Commentarii IIII. Iam Recens Studiosis Restituti, Et A'Mendis Quantum Fieri Potuit Repurgati. [...] Cum Indice [...] cum rerum tum verborum.

Francforti: Christianus Aegenolphus, 1535; $2^{\circ}$.

VD16 F 683.

Prow.: 1. Stanisław Karnkowski - pieczęć.

2. Inscriptus catalogo librorum Seminarij Eccl(esi)ae Metropol(ita) nae Gnesnen(sis) Congr(egationis) Missionis.

Oprawa: tektura, pergamin, wiązania rzemienne.

\section{Gambiglioni Angelo}

AAG, sygn. BK 11074

Super Institu(tiones) Opus preclarum viri prestantissimi [...] Angeli aretini [...] sup(er) q(ua)rta parte institutionu(m) cu(m) casibus longis [...] Francisci de aretio [...] positis quide $(m)$ in margine [...] Cui nuper sup[er]additus est index alphabeticus [...].

Lugduni: Antonius du Ry, impensis Jacobi Giunta et sociorum, 1523; $4^{\circ}$.

ICCU (online).

Prow.: 1. Stanisław Karnkowski — pieczęć. 
2. Ex Libr(is). Admod(um). R(evere)ndi. D(omini). Vincentii de Seue I(uris). V(triusque). D(octoris). Lascen(sis). et Louicien(sis). Praepo(si)ti. Archidiaconi. Gnesnen(sis).

Oprawa: tektura, pergamin, tkane wiązania; warsztat gdański (?).

\section{Gambiglioni Angelo}

AAG, sygn. BK 1048

Super Institu(tiones) Opus preclarum viri prestantissimi [...] Angeli aretini [...] $\sup [\mathrm{er}] \mathrm{q}(\mathrm{ua})$ ttuor libris institutionu(m) $\mathrm{cu}(\mathrm{m})$ casibus longis [...] Francisci de aretio [...] positis quide(m) in margine [...] Cui nuper sup(er)additus est index alphabeticus [...].

Lugduni: Antonius du Ry, impensis Jacobi Giunta et sociorum, 1523; $4^{\circ}$.

ICCU (online).

Prow.: 1. Stani(slaus). Dambrowski.

2. Stanisław Karnkowski - pieczęć.

3. Ex Libr(is). Admod(um). R(evere)ndi. D(omini). Vincentii de Seue I(uris). V(triusque). D(octoris). Lascen(sis). et Louicien(sis). Praepo(si)ti. Archidiaconi. Gnesnen(sis).

4. Ex Bibliotheca R(evere)ndi(ssi)mi Capituli Metropolitani Gnesnensi(s).

Oprawa: tektura, pergamin, tkane wiązania; warsztat gdański (?).

\section{Iohannes von Deventer}

AAG, sygn. BK 725

Exegesis Absolutissima Iuxta ac brevissima Evangelicae veritatis, erorrumque $\&$ mendaciorum quae sunt cum in Confessione Lutherana Caesa(rea) Maiestati in comitis Augusten(sibus) exhibita.

Coloniae: Melchior Novesianus, $1535 ; 2^{\circ}$.

VD16 J 547.

Prow.: 1. Stanisław Karnkowski - pieczęć.

2. Albertus Bagiński C(anonicus) V(nieioviensis) P(lebanus) Koninensis.

3. Post mortem nomine legati Seminarii Gnesnensis.

Oprawa: XX wiek, tektura, jasna skóra.

\section{Junga Adrian}

AAG, sygn. PL 108b adl.

Messiasz Albo Kazania o Upadku Y Naprawie Rodzaiu Ludzkiego, Przez Przyście na świat Pana naszego Jezusa Christusa Syna Bożego; Przydane na końcu tegosz Auctora, O Dwoiakim Kosciele Chrześcijańskim.

E 19, 120. Wojciechowska, Wolrab, poz. 110 (por. PSB 11, 326).

Poznań: [Barbara Wolrabowa i dzieci], 1597; $2^{\circ}$.

Prow.: 1. Stanisław Karnkowski - superekslibris: typ IV, wariant II.

2. IE(g)o M(ości). X(iędzu). Biskupowi Ploczkiemu Autor D(at) [Wojciech Baranowski].

Oprawa: tektura, pergamin, tłocz. złoc., napis gotycki na grzbiecie.

AAG, sygn. PL 322 


\section{Kromer Marcin}

Monachus sive colloquiorum de religione libri IV.

Coloniae: Maternus Cholinus, 1568; $8^{\circ}$.

E 20, 279. Formanowicz poz. 200 (War. A - egzemplarz zawiera tylko trzy pierwsze księgi).

Prow.: 1. Stanisław Karnkowski - pieczęć.

2. Gaspari Haczel Mokrski Canonici Posnaniensis m(anu) p(ropria).

3. Sum Ecclesiae Nowomestensis.

Oprawa: tektura, pergamin, rzemienne wiązania.

\section{Martinus Polonus}

AAG, sygn. PL 69

Margarita Decreti, Seu Tabula Martiniana.

[Norimbergae: Antonius Koberger, 1491/3]; $2^{\circ}$.

IBP 3625.

Prow.: 1. Stanisław Karnkowski — pieczęć.

2. Inscriptus catalogo libror(um). Seminarij Eccl(esi)ae Metropol(ita) nae Gnesnen(sis). Congreg(ationis). Missionis.

Oprawa: tektura, pergamin, rzemienie; warsztat krakowski (?).

\section{Placentinus}

AAG, sygn. Inc. 655

In Codicis Dn Iustiniani Sacratissimi Principis Ex Repetita Praelectione Libros IX. Summa [...]. Nunc Primum In Lucem Aedita. Accessit Praeterea Index Geminus [...].

Moguntiae: Ivo Schoeffer, 1536; $2^{\circ}$.

VD16 P 1887.

Prow. i opr. zob. poz. 23.

\section{Pontano Lodovico}

AAG, sygn. BK 11074

\section{Consilia [...].}

Lugduni: Iacobus Giunta, 1545; $2^{\circ}$.

ICCU (online); KVK (online).

Prow.: 1. Stanislai Karnkowski i pieczęć.

2. Ex Libr(is). Admod(um). R(evere)ndi. D(omini). Vincentii de Seue I(uris). V(triusque). D(octoris). Lascen(sis). et Louicien(sis). Praepo(si)ti. Archidiaconi. Gnesnen(sis).

3. Ex Bibliotheca R(evere)nd(issi)mi Capituli Gnesnen(sis).

Oprawa: tektura, pergamin, tłocz. złoc., tkane wiązania; warsztat gdański (?).

\section{Rej Mikolaj}

AAG, sygn. BK 1364

Catechismus, to jest nauka barzo pożyteczna każdemu krześcijaninowi, jako się ma w zakonie Bożym a w wierze i dobrych uczynkach sprawować.

Kraków: Helena Unglerowa, ok. 1543; $8^{\circ}$. 
Formanowicz poz. 53.

Prow. i opr. zob. poz. 26.

\section{Thomas Aquinatus $S$.}

AAG, sygn. PL 108b adl.

Quaestiones Disputatae [...] De Potentia Dei, De Malo, De Spiritualibus Creaturis, De Anima, De Daemonibus, De Angelis, De Veritate, Et pluribus aliis Quaestionibus [...].

Parisiis: Franciscu de Honoratis, 1557, $2^{\circ}$.

Adams A-1408; ICCU (online).

Prow.: 1. Stanisław Karnkowski - pieczęć.

2. Inscriptus catalogo Collegij Posnan(iensis).

3. Franciscus Moller Ordinis S Francisci de Obser(v)a(nt)ia Ind[...] orum (?) reliquet p(ro) loco Lobsinensi Guardian(us) p(ro) tunc eiusdem loci 1663.

4. Con(ven)t(us) Gorcensis Ad Sancta V(irginis)M(ariae):

Oprawa: deska fazowana, brązowa skóra, tłocz. złoc. i ślepe, zapięcia mosiężno-skórz.; warsztat krakowski (?).

\section{Tiraqueau André}

AAG, sygn. BKS 745

De Utroque Retractu, Municipali, Et Conventionali, Commentarii Duo [...].

Lugduni: Gulielmus Rovilius, 1554, $2^{\circ}$.

ICCU (online); KVK (online).

Prow.: 1. Sum Stanislai Carncowski Referendarii Cvriae Sacre R(egiae) M(aiesta)tis i pieczęć.

2. Ex Libr(is). Admod(um). R(evere)ndi. D(omini). Vincentii de Seue I(uris). V(triusque). D(octoris). Lascen(sis). et Louicien(sis). Praepo(si)ti. Archidiaconi. Gnesnen(sis).

Oprawa: tektura, biała świńska skóra, tłocz. ślepe; warsztat Johann von Sachsen (Marburg).

\section{Vazquez Menchaca Fernando}

AAG, sygn. BKS 1196

Illustrium Controversiarum Aliarumque Usu Frequentium Libri tres [...].

[Genevae]: Franciscus Faber [et] Iacobus Stoer, 1595; $4^{\circ}$.

$\mathrm{KVK}$ (online); COPAC (online)

Prow.: 1. Stanisław Karnkowski - superekslibris: typ V, wariant II.

2. Ex Libr(is). Admod(um). R(evere)ndi. D(omini). Vincentii de Seue I(uris). V(triusque). D(octoris). Lascen(sis). et Louicien(sis). Praepo(si)ti. Archidiaconi. Gnesnen(sis).

3. Ex Bibliotheca R(evere)nd(issi)mi Capituli Gnesnen(sis).

Oprawa: tektura, pergamin, rzemienie, tłocz. złoc.; warsztat poznański (?).

AAG, sygn. BK 845 


\section{Vincentius Bellovacensis}

Speculum morale

[Strassburg: Ioannes Mentelin, 1476]; $2^{\circ}$. — Var. A.

IBP 5651.

Prow.: 1. Stanisław Karnkowski - pieczęć.

2. Inscriptus catalogo Collegij Posnan(iensis).

Oprawa: tektura, brązowa skóra, tłocz. złoc.; warsztat krakowski (?).

\section{Zasius Ulrich}

AAG, sygn. Inc. 321

In Usus Feudorum Epitome, Ordine Et Utilitate Commendabilis. Eiusdem Orationes Aliquot disertae, tum in laudem Legum, tum funebres.

Basileae: Iohannes Bebelius, 1535; $2^{\circ}$.

VD16 Z 158.

Prow. i opr. zob. poz. 23.

\section{Zini Pietro Francesco}

AAG, sygn. BK 11074

Boni Pastoris Exemplum Ac Specimen Singulare.

Venetiis: Franciscus Rampazetus, 1556; $8^{\circ}$.

EDIT16 (online; CNCE 36257).

Prow. i opr. zob. poz. 14.

AAG, sygn. BKS 5251

\section{MICHAŁ BARTOSZAK}

\section{THE REMAINS OF PRIMATE STANISŁAW KARNKOWSKI'S BOOK COLLECTION \\ IN THE ARCHDIOCESAN ARCHIVES IN GNIEZNO}

\section{Summary}

The book collection amassed by Primate Stanisław Karnkowski and regarded as one of the wealthiest Polish libraries in the late 16th and early 17th century comprised 322 books, according to Stanisław Rybandt's estimates from 1992. 22 more books from the second interrex's collection were found during a search conducted in the Archdiocesan Archives in Gniezno in 2012-2017. A thematical analysis of the books, which points to the primate's interest in legal and theological literature, is complemented in the second part of the article by a presentation of the types of ownership marks as well as a discussion of binding-related questions. The author pays particular attention to unknown or never reproduced variants of the supralibros used in the books.

KEY WORDS: Archdiocesan Archives in Gniezno, Stanisław Karnkowski, old printed books, provenance studies 